\title{
A Latent Mechanoacid for Time-Stamped Mechanochromism and Chemical Signaling in Polymeric Materials
}

\author{
Yangju Lin, Tatiana B. Kouznetsova and Stephen L. Craig* \\ Department of Chemistry, Duke University, Durham, North Carolina 27708, United States
}

\section{Contents}

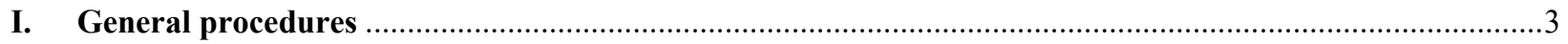

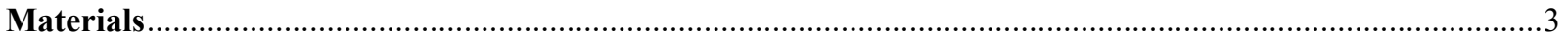

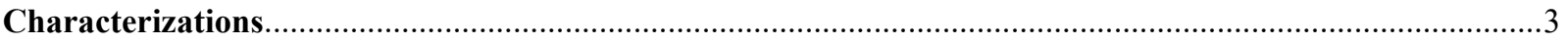

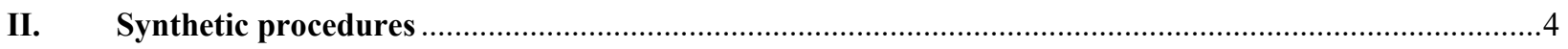

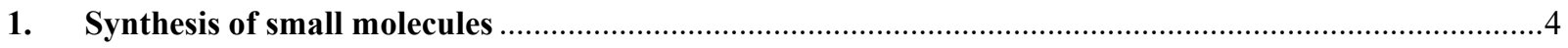

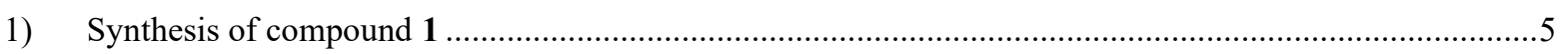

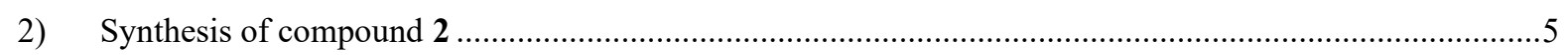

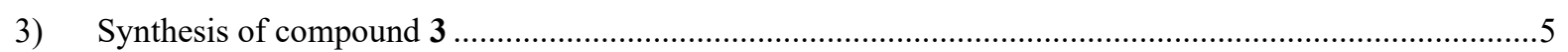

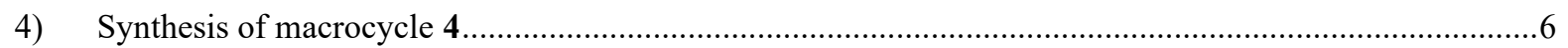

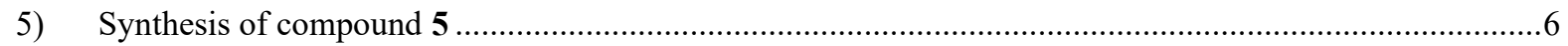

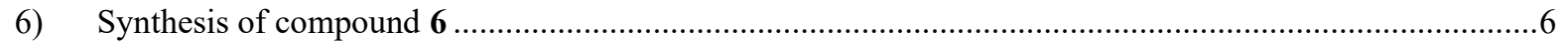

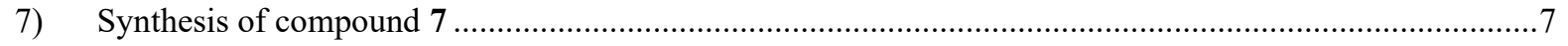

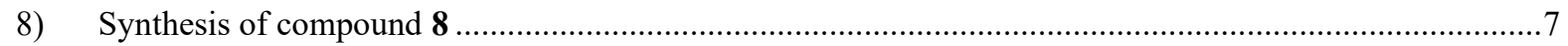

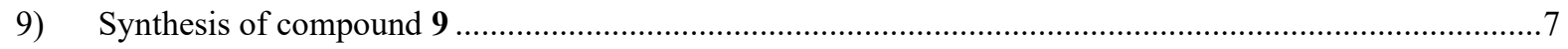

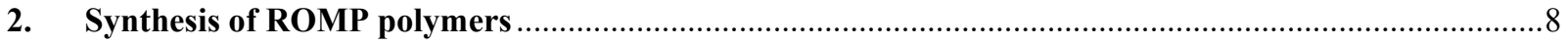

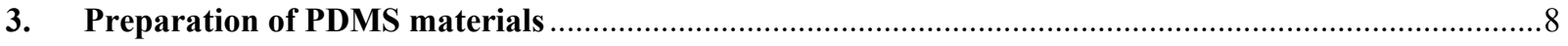

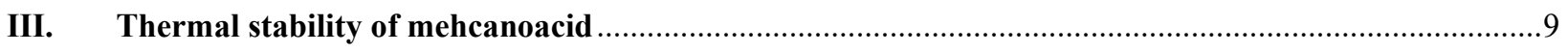

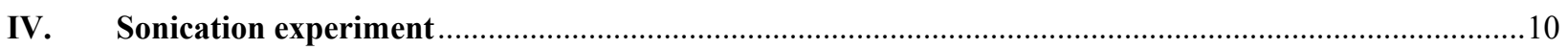

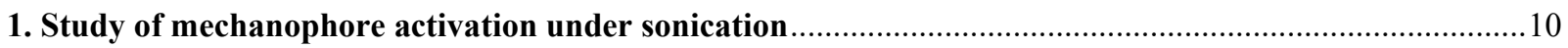

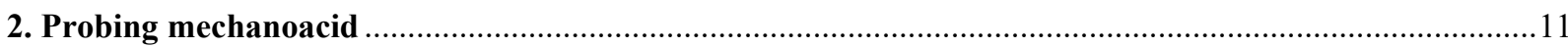

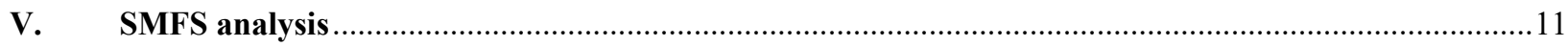

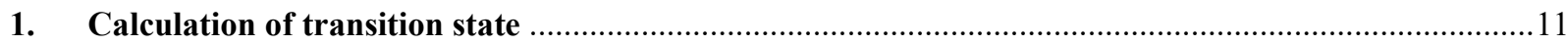

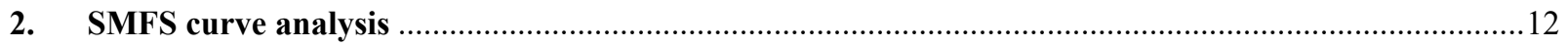

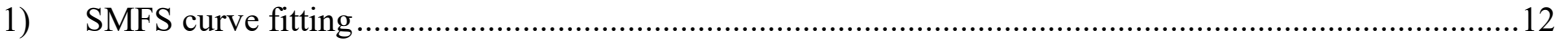

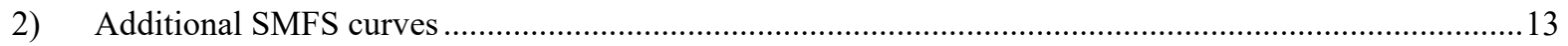

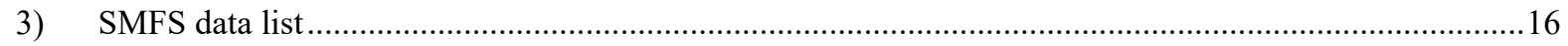

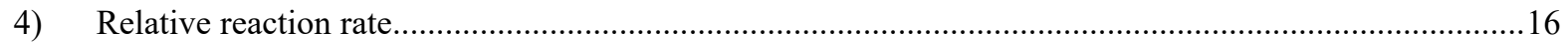

VI. Generation and labeling of mechanoacid in PDMS elastomer ................................................17

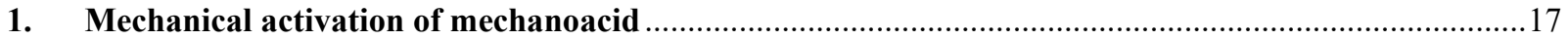




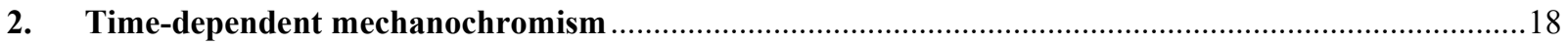

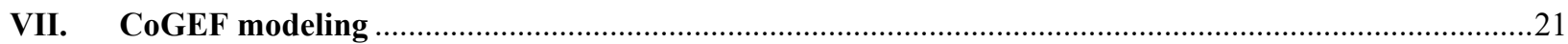

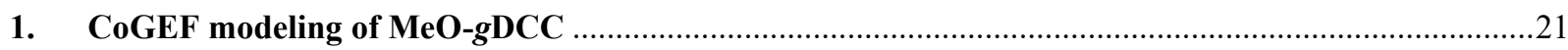

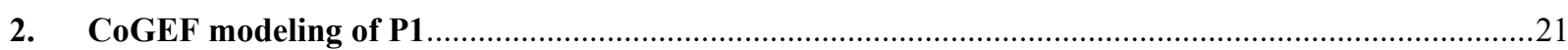

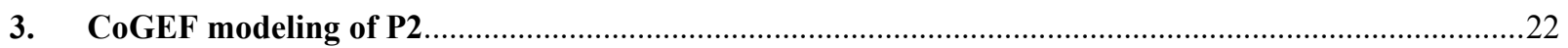

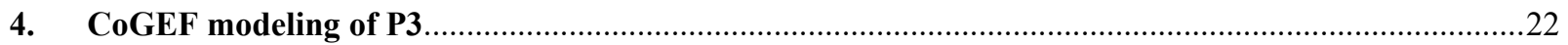

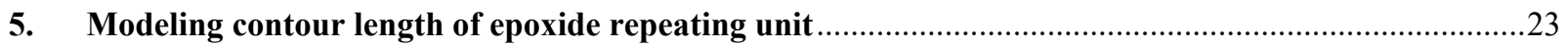

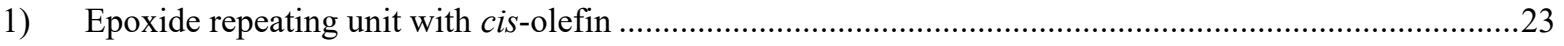

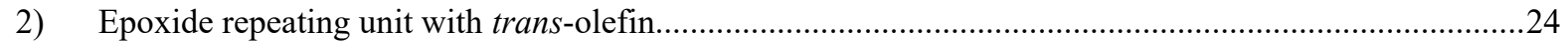

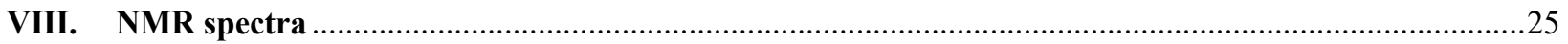

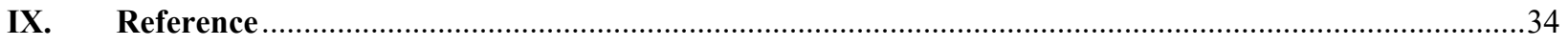




\section{General procedures}

\section{Materials}

Lab general solvents (dichloromethane, chloroform, hexane, ethyl acetate, acetone, toluene, tetrahydrofuran, methanol) were purchased from VWR or Sigma Aldrich. 1-methoxy-1, 4-cyclohexadiene, $\mathrm{NaOH}$ powder, sodium borohydride, 4-pentenoic anhydride, dimethyl aminopyridine (DMAP), rhodamine B base, p-Toluenesulfonyl chloride, aminoethanol, 7-octenoic acid, 1, 2-epoxy-5-cyclooctene, Grubbs 2 catalyst were purchased from Sigma Aldrich or Alfa Aesar and used without further purification. Sylgard $₫ 184$ was purchased from Ellsworth Adhesives, Germantown, WI. Flash chromatography was performed on CombiFlash ${ }^{\circledR 2} 20$ auto-column system from Teledyne ISCO.

\section{Characterizations}

${ }^{1} \mathrm{H}$ NMR spectra were collected on a $400 \mathrm{MHz}$ Varian INOVA spectrometer and ${ }^{13} \mathrm{C}$ NMR spectra were collected on a $500 \mathrm{MHz}$ Varian UNITY spectrometer. Chemical shifts are given in $p p m(\delta)$ and referenced to the residual ${ }^{1} \mathrm{H}$ peak at $7.26 \mathrm{ppm}$ or ${ }^{13} \mathrm{C}$ peak at $77.16 \mathrm{ppm}$ in $\mathrm{CDCl}_{3} .{ }^{1} \mathrm{H}$ shifts are reported as chemical shift, multiplicity, coupling constant if applicable, and relative integral. Multiplicities are reported as: singlet (s), doublet (d), doublet of doublets (dd), doublet of triplets (dt), doublet of doublet of doublets (ddd), doublet of doublet of triplets (ddt), triplet (t), triplet of doublets (td), quartet (q), multiplet (m), or broad (br). Coupling constants (J) are reported in Hertz. High-resolution mass spectra were collected on an Agilent LCMS-TOF-DART at Duke University's Mass Spectrometry Facility. Gel permeation chromatography (GPC) was performed on two Agilent PLgel mixed-C columns $\left(10^{5} \AA, 7.5 \times 300 \mathrm{~mm}, 5\right.$ $\mu \mathrm{m}$, part number PL1110-6500) using THF (stabilized with $100 \mathrm{ppm}$ BHT) as the eluent. Molecular weights were calculated using a Wyatt Dawn EOS multi-angle light scattering (MALS) detector and Wyatt Optilab DSP Interferometric Refractometer (RI). The refractive index increment $(\mathrm{dn} / \mathrm{dc})$ values were determined by online calculation based on injections of known concentration and mass. UV-vis spectra were collected on a Varian Cary $500 \mathrm{UV}-\mathrm{Vis}$ Spectrophotometer.

Sharp Microlever silicon probes (MSNL) and Silicon Nitride AFM Probes (PNP-DB) were correspondingly purchased from Bruker (Camarillo, CA) and NanoAndMore(Watsonville, CA). All of the SMFS studies were conducted at ambient temperature $\left(\sim 23^{\circ} \mathrm{C}\right)$ using a homemade AFM, which was constructed using a Digital Instruments scanning head mounted on top of a piezoelectric positioner, similar to the one described in detail previously..$^{1-2}$ The AFM pulling experiments were conducted in a solution of toluene. The spring constant of each cantilever was calibrated in air, using the thermal noise method, based on the energy equipartition theorem as described previously. ${ }^{1-2}$ Measurements were carried out in a closed fluid cell with a scanning set for a series of approaching/retracting cycles. Probes were prepared by immersing in piranha solution $\left(\mathrm{H}_{2} \mathrm{SO}_{4}: \mathrm{H}_{2} \mathrm{O}_{2}=3: 1\right)$ for 15 minutes at room temperature and then immersing in deionized water and dried by touching them against a borohydride. Silicon substrates were prepared by first allowing each to soak in hot piranha solution for 30 minutes and then washed with deionized water and dried under a stream of nitrogen. Caution should be used when handling piranha solution: it has been reported to detonate unexpectedly. The substrate and the cantilever were then placed in a UVO cleaner (ozone produced through UV light) for 15 minutes. After ozonolysis, the cantilever was mounted in the fluid cell. $20 \mu \mathrm{L}$ of a $0.05-0.1 \mathrm{mg} / \mathrm{mL}$ polymer solution was added to the silicon substrate surface and allowed to dry. The silicon substrate was then placed on the piezoelectric stage of the AFM. Force curves were collected in dSPACE (dSPACE Inc. Wixom, MI) and analyzed using Matlab (The MathWorks, Inc., Natick, MA). All data were filtered during acquisition at $500 \mathrm{~Hz}$. After acquisition, the data were calibrated and plotted by using homemade software written in Matlab language. 


\section{Synthetic procedures}

\section{Synthesis of small molecules}

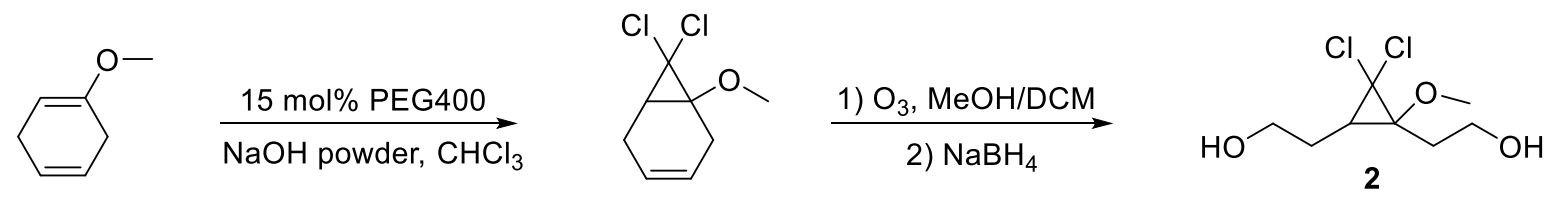

1
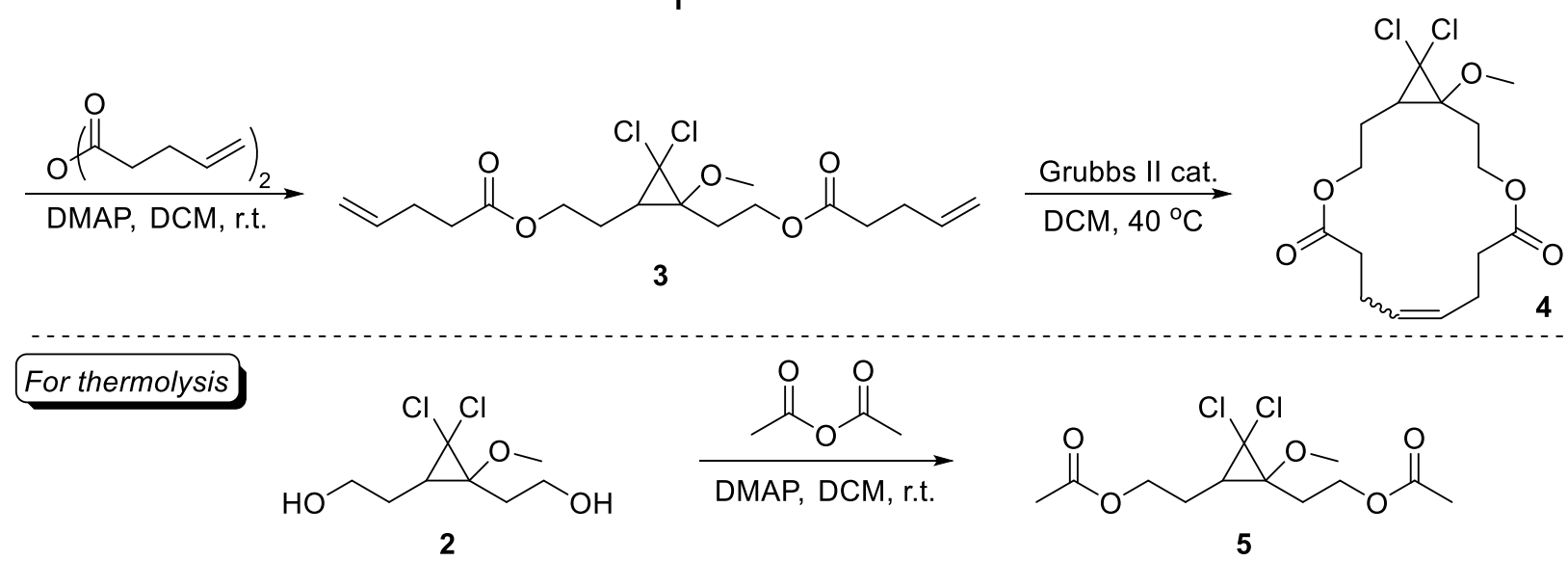

\section{Control}<smiles>COC1(CCO)C(CCO)C1(Cl)Cl</smiles><smiles>CCCCCCC(=O)O</smiles><smiles>C=CCCC(=O)OCCC1C(Cl)(Cl)C1(CCO)OC</smiles><smiles>CC(=O)OC(C)=O</smiles><smiles>C=CCCC=O</smiles><smiles>COC1(CCOC=O)C(CCOC(C)=O)C1(Cl)Cl</smiles><smiles>[3H][I-]</smiles><smiles>C=CCCC(=O)OCCC1C(Cl)(Cl)C1(CCOC(C)=O)OC</smiles><smiles>CCN(CC)c1ccc2c(c1)Oc1cc(N(CC)CC)ccc1C21OC(=O)c2ccccc21</smiles>

Rhodamine B Base
1) $\underset{\mathrm{TsCl} \text {; 2) } \mathrm{DMAP}}{\stackrel{\mathrm{H}}{\longrightarrow}}$

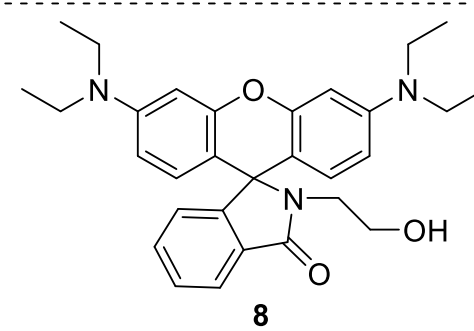<smiles>CC=CCCCCCC(=O)O</smiles><smiles>CCN(C)CC</smiles><smiles>CCC(=O)OCCN1C(=O)c2ccccc2C12c1ccccc1Oc1cc(N(CC)CC)ccc12</smiles> 


\section{1) Synthesis of compound 1}
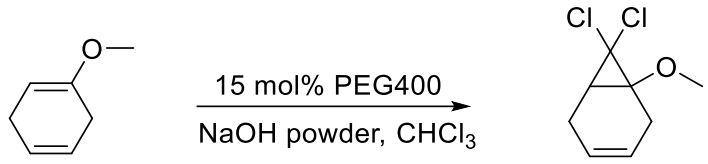

1

The synthesis of methoxyl substituded gem-dichlorocyclopropane (MeO-gDCC) was performed using reported protocol. $^{3}$

To a solution of 1-methoxy-1, 4-cyclohexadiene $(1.10 \mathrm{~g}, 10 \mathrm{mmol})$ in $20 \mathrm{~mL}$ of chloroform, added PEG400 $\left(M_{\mathrm{n}}=\right.$ $400,600 \mathrm{mg}, 1.5 \mathrm{mmol})$ as phase transfer catalyst. The solution was cooled with an ice bath. $\mathrm{NaOH}$ powder $(1.2 \mathrm{~g}, 30$ $\mathrm{mmol}$ ) was then added in portions. The solution turned dark green. After stirred for $30 \mathrm{~min}, 100 \mathrm{~mL}$ of $\mathrm{Et}_{2} \mathrm{O}$ was added to the mixture. Insoluble solid was filtered, and the filtrate was washed with $25 \mathrm{~mL} 1 \mathrm{~N} \mathrm{HCl}, 5 \times 25 \mathrm{~mL}$ DI water and then $25 \mathrm{~mL}$ brine. The organic phase was further dried with $\mathrm{MgSO}_{4}$. After filtration, the solvent was removed under reduced pressure, a colorless liquid was obtained $(1.90 \mathrm{~g}, 98 \%) .{ }^{1} \mathrm{H}$ and ${ }^{13} \mathrm{C}$ NMR indicated $>90 \%$ purity of compound 1. This liquid was used without further purification. ${ }^{1} \mathrm{H}$ NMR $\left(400 \mathrm{MHz}, \mathrm{CDCl}_{3}\right): \delta 5.54(\mathrm{~m}, 2 \mathrm{H}), 3.49$. (s, 3H), 2.74 $-2.49(\mathrm{~m}, 3 \mathrm{H}), 2.30-2.16(\mathrm{~m}, 1 \mathrm{H}), 1.84(\mathrm{~d}, J=7.93 \mathrm{~Hz}, 1 \mathrm{H}) .{ }^{13} \mathrm{C} \mathrm{NMR}\left(125 \mathrm{MHz}, \mathrm{CDCl}_{3}\right): \delta 122.60,122.17,67.37$, $63.62,54.56,31.52,24.13,21.09$.

\section{2) Synthesis of compound 2}
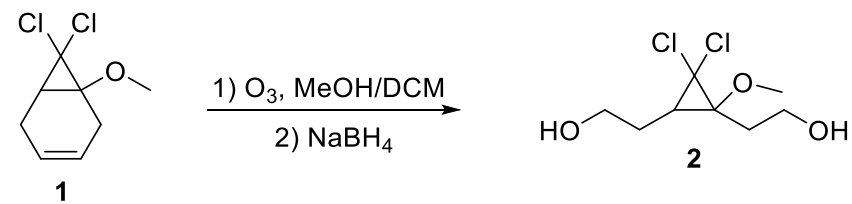

Compound $1(0.965 \mathrm{~g}, 5 \mathrm{mmol})$ was dissolved in $15 \mathrm{~mL}$ of methanol/DCM $(2: 1)$. The solution was cooled to $-78{ }^{\circ} \mathrm{C}$ and $\mathrm{O}_{3}$ was then bubbled through. The solution turned blue after $10 \mathrm{~min}$. TLC (25\% EtOAc/Hexane) indicated that the reactant had been completely consumed. $\mathrm{O}_{2}$ was then bubbled through to remove excess $\mathrm{O}_{3}$. The solution turned colorless after $15 \mathrm{~min} . \mathrm{NaBH}_{4}$ solid $(950 \mathrm{mg}, 50 \mathrm{mmol})$ was then added in portions at $-78^{\circ} \mathrm{C}$. The mixture was slowly warmed to r.t. and stirred for overnight. After the reaction completed, $\mathrm{MeOH}$ was removed and $25 \mathrm{~mL}$ DI water was added to the residual. The mixture was extracted with $3 \times 25 \mathrm{~mL} \mathrm{Et}_{2} \mathrm{O}$. The combined organic phase was dried with $\mathrm{MgSO}_{4}$ and condensed. Residual was purified with flash chromatography (0 100\% EtOAc/Hexane gradient elution) to give compound 2 as a colorless oil (867 mg, $77.8 \%)$. ${ }^{1} \mathrm{H}$ NMR (400 MHz, $\left.\mathrm{CDCl}_{3}\right): \delta 3.96-3.73(\mathrm{~m}, 4 \mathrm{H}), 3.46$. (s, $3 \mathrm{H}), 2.20-2.10(\mathrm{~m}, 2 \mathrm{H}), 2.02-1.91(\mathrm{~m}, 1 \mathrm{H}), 1.75(\mathrm{~m}, 2 \mathrm{H}) .{ }^{13} \mathrm{C} \mathrm{NMR}\left(125 \mathrm{MHz}, \mathrm{CDCl}_{3}\right): \delta 68.26,67.34,61.02,58.86$, 54.83, 37.13, 28.94, 28.20. HRMS-ESI $(\mathrm{m} / \mathrm{z})$ : $[\mathrm{M}+\mathrm{H}]^{+}$calculated for $\mathrm{C}_{8} \mathrm{H}_{14} \mathrm{Cl}_{2} \mathrm{O}_{3}, 229.03928$; observed, 229.03865.

\section{3) Synthesis of compound 3}
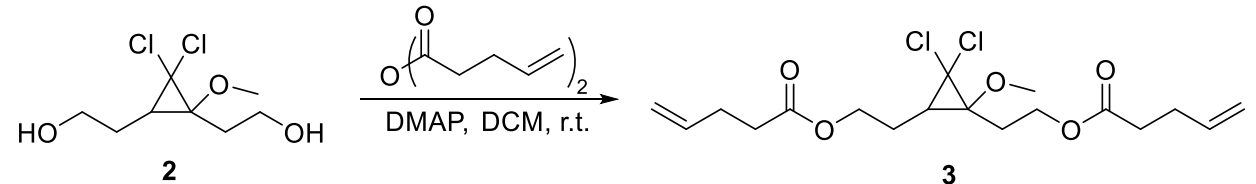

To a solution of compound 2 ( $458 \mathrm{mg}, 2 \mathrm{mmol})$ in $10 \mathrm{~mL}$ of DCM, added DMAP (24.4 mg, $0.2 \mathrm{mmol})$. Pentenoic anhydride $(766 \mu \mathrm{L}, 4.2 \mathrm{mmol})$ was then added dropwise to the solution. After stirred at room temperature for overnight, DMC was removed. The residual was purified by flash chromatography (0 25\% EtOAc/Hexane gradient elution) to give product 3 as a colorless oil (716 mg, 91.1\%). ${ }^{1} \mathrm{H}$ NMR (400 MHz, $\left.\mathrm{CDCl}_{3}\right): \delta 5.92-5.69(\mathrm{~m}, 2 \mathrm{H}), 5.16-4.94$ $(\mathrm{m}, 4 \mathrm{H}), 4.27(\mathrm{t}, J=7.1 \mathrm{~Hz}, 2 \mathrm{H}), 4.21(\mathrm{t}, J=6.3 \mathrm{~Hz}, 2 \mathrm{H}), 3.43(\mathrm{~s}, 3 \mathrm{H}), 2.51-2.32(\mathrm{~m}, 8 \mathrm{H}), 2.23(\mathrm{~m}, 1 \mathrm{H}), 2.04-1.92$ $(\mathrm{m}, 1 \mathrm{H}), 1.92-1.71(\mathrm{~m}, 2 \mathrm{H}), 1.67(\mathrm{dd}, J=8.3,5.7 \mathrm{~Hz}, 1 \mathrm{H}) .{ }^{13} \mathrm{C}$ NMR $\left(125 \mathrm{MHz}, \mathrm{CDCl}_{3}\right): \delta 172.85,136.58,115.64$, $67.34,67.22,62.47,60.16,54.66,36.40,33.49,28.81,25.38,24.98$. HRMS-ESI $(m / z):[\mathrm{M}+\mathrm{H}]^{+}$calculated for $\mathrm{C}_{18} \mathrm{H}_{26} \mathrm{Cl}_{2} \mathrm{O}_{5}, 393.12301$; observed, 393.12223. 


\section{4) Synthesis of macrocycle 4}
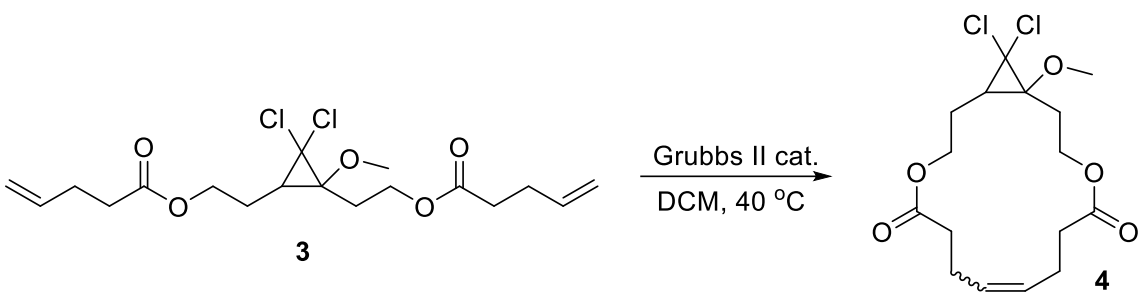

Compound 3 (393 mg, $1 \mathrm{mmol}$ ) was dissolved in $500 \mathrm{~mL}$ of DCM, and the solution was bubbled with $\mathrm{N}_{2}$ for $10 \mathrm{~min}$. Grubbs catalyst $2(85 \mathrm{mg}, 0.1 \mathrm{mmol})$ was added in one portion. The solution was heated at $40{ }^{\circ} \mathrm{C}$ for overnight. After completion, solution was condensed onto silica. Pure macrocycle 4 was obtained as a colorless oil (343 mg, 94.0\%) after flash chromatography $(0 \sim 25 \%$ EtOAc/Hexane gradient elution). The oil solidified after standing for several days. ${ }^{1} \mathrm{H}$ NMR (400 MHz, $\left.\mathrm{CDCl}_{3}\right): \delta 5.56-5.35(\mathrm{~m}, 2 \mathrm{H}), 4.54-4.42(\mathrm{~m}, 1 \mathrm{H}), 4.54-4.27(\mathrm{~m}, 2 \mathrm{H}), 4.16-3.97(\mathrm{~m}, 1 \mathrm{H})$, $3.47(\mathrm{~s}, 3 \mathrm{H}), 2.56-2.18(\mathrm{~m}, 8 \mathrm{H}), 2.15-2.06(\mathrm{~m}, 1 \mathrm{H}), 2.02-1.91(\mathrm{~m}, 1 \mathrm{H}), 1.89-1.75(\mathrm{~m}, 1 \mathrm{H}), 1.73-1.60(\mathrm{~m}, 2 \mathrm{H})$. ${ }^{13} \mathrm{C} \mathrm{NMR}\left(125 \mathrm{MHz}, \mathrm{CDCl}_{3}\right): \delta 172.80,172.33,130.10,129.80,67.08,66.46,62.06,59.52,54.65,37.00,34.69,34.52$, 28.21, 26.63, 25.81. HRMS-ESI $(\mathrm{m} / \mathrm{z})$ : $[\mathrm{M}+\mathrm{H}]^{+}$calculated for $\mathrm{C}_{16} \mathrm{H}_{22} \mathrm{Cl}_{2} \mathrm{O}_{5}, 365.09171$; observed, 365.09145 .

\section{5) Synthesis of compound 5}
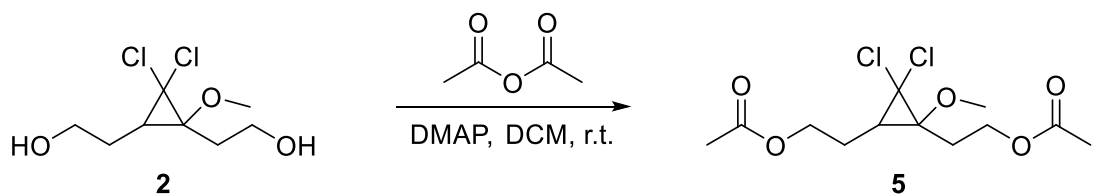

To a solution of $2(229 \mathrm{mg}, 1 \mathrm{mmol})$ in $3 \mathrm{~mL}$ of DCM, added DMAP $(6.1 \mathrm{mg}, 0.05 \mathrm{mmol})$. Acetic anhydride (284 uL, $3 \mathrm{mmol}$ ) was then added dropwise to the solution. The reaction was stirred at r.t. for overnight. After the reaction completed, the solvent was removed and product was purified by flash chromatography (0 25\% EtOAc/hexane gradient). A colorless liquid 5 was obtained $(215 \mathrm{mg}, 68.6 \%) .{ }^{1} \mathrm{H}$ NMR $\left(400 \mathrm{MHz}, \mathrm{CDCl}_{3}\right): \delta 4.26$ (td, $J=7.0,1.2$ $\mathrm{Hz}, 2 \mathrm{H}), 4.20(\mathrm{td}, J=6.4,0.9 \mathrm{~Hz}, 2 \mathrm{H}), 3.43(\mathrm{~s}, 3 \mathrm{H}), 2.24(\mathrm{~m}, 1 \mathrm{H}), 2.09(\mathrm{~s}, 3 \mathrm{H}), 2.07(\mathrm{~s}, 3 \mathrm{H}), 2.03-1.92(\mathrm{~m}, 1 \mathrm{H}), 1.91$ $-1.71(\mathrm{~m}, 2 \mathrm{H}), 1.67(\mathrm{dd}, J=8.1,6.0 \mathrm{~Hz}, 1 \mathrm{H}) .{ }^{13} \mathrm{C} \mathrm{NMR}\left(125 \mathrm{MHz}, \mathrm{CDCl}_{3}\right): \delta 171.02,67.41,67.26,62.62,60.25$, 54.72, 36.50, 25.41, 25.00, 21.09, 21.02. HRMS-ESI $(m / z)$ : $[\mathrm{M}+\mathrm{H}]^{+}$calculated for $\mathrm{C}_{12} \mathrm{H}_{18} \mathrm{Cl}_{2} \mathrm{O}_{5}, 313.06041$; observed, 313.06007 .

6) Synthesis of compound 6
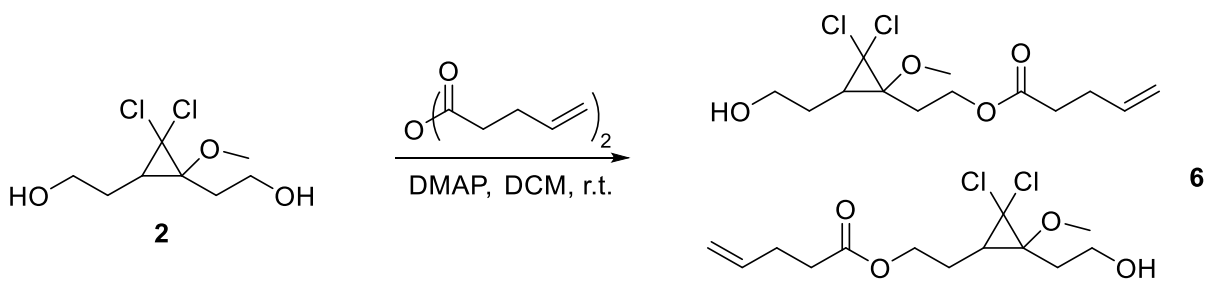

In a $20 \mathrm{~mL}$ scintillation vial, added compound $2(140 \mathrm{mg}, 0.6 \mathrm{mmol})$, DMAP $(7.3 \mathrm{mg}, 0.06 \mathrm{mmol})$ and $3 \mathrm{~mL}$ DCM. Then, 4-pentenoic anhydride $(110 \mu \mathrm{L}, 0.6 \mathrm{mmol})$ was then added dropwise to the solution. The reaction was stirred overnight. After the reaction completed, $100 \mu \mathrm{L}$ triethylamine was then added. DCM was removed and residual was subjected to flash chromatography (0 50\% EtOAc/hexane eluent). Compound $\mathbf{6}$ was obtained as a colorless liquid (82 mg, 43.9\%). ${ }^{1} \mathrm{H}$ NMR (400 MHz, $\mathrm{CDCl}_{3}$ ): $\delta=5.83$ (ddt, $\left.J=16.5,10.1,6.1 \mathrm{~Hz}, 1 \mathrm{H}\right), 5.14-4.95(\mathrm{~m}, 2 \mathrm{H}), 4.36-$ $-4.19(\mathrm{~m}, 2 \mathrm{H}), 3.93-3.81(\mathrm{~m}, 2 \mathrm{H}), 3.44 \& 2.97(\mathrm{~s}, 3 \mathrm{H}), 2.50-2.34(\mathrm{~m}, 4 \mathrm{H}), 2.23-1.96(\mathrm{~m}, 1 \mathrm{H}), 1.96-1.63 \& 1.52$ (m\&t, $J=5.2 \mathrm{~Hz}, 4 \mathrm{H}) .{ }^{13} \mathrm{C}$ NMR $\left(125 \mathrm{MHz}, \mathrm{CDCl}_{3}\right): \delta 173.17,173.11,136.75,136.69,115.81,115.74,68.56,67.63$, $67.60,62.67,61.32,60.45,59.60,54.91,54.81,36.70,36.56,33.68,33.65,29.11,28.95,28.93,28.22,25.62,25.21$. HRMS-ESI $(m / z)$ : $[\mathrm{M}+\mathrm{H}]^{+}$calculated for $\mathrm{C}_{13} \mathrm{H}_{20} \mathrm{Cl}_{2} \mathrm{O}_{4}, 311.08114$; observed, 311.08078 . 


\section{7) Synthesis of compound 7}
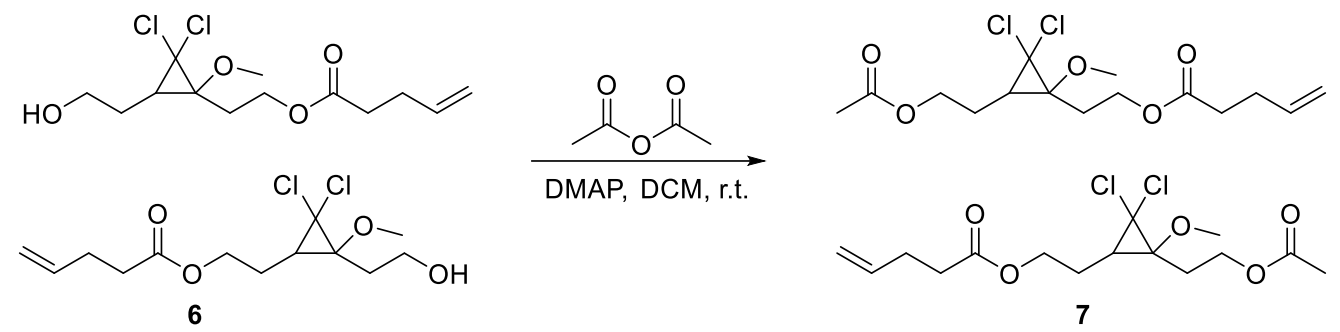

To a solution of compound 6 (66 mg, $0.21 \mathrm{mmol})$ and DMAP $(2.5 \mathrm{mg}, 0.02 \mathrm{mmol})$ in $2 \mathrm{~mL} \mathrm{DCM}$, added acetic anhydride $(40 \mathrm{mg}, 0.42 \mathrm{mmol}$ ) dropwise. The reaction was stirred overnight. The product was purified by flash chromatography (0 30\% EtOAc/hexane gradient). Compound 7 was obtained as a colorless oil $(65.5 \mathrm{mg}, 88.4 \%) .{ }^{1} \mathrm{H}$ NMR (400 MHz, $\left.\mathrm{CDCl}_{3}\right): \delta=5.82(\mathrm{ddtd}, J=16.3,10.3,6.2,1.4 \mathrm{~Hz}, 1 \mathrm{H}), 5.13-4.94(\mathrm{~m}, 2 \mathrm{H}), 4.32-4.15(\mathrm{~m}, 4 \mathrm{H})$, $3.42(\mathrm{~s}, 3 \mathrm{H}), 2.51-2.32(\mathrm{~m}, 4 \mathrm{H}), 2.23(\mathrm{dtd}, J=16.4,7.0,2.3 \mathrm{~Hz}, 1 \mathrm{H}), 2.08 \& 2.07(\mathrm{~s}, 3 \mathrm{H}), 1.97(\mathrm{~m}, 1 \mathrm{H}), 1.90-1.82$ $(\mathrm{m}, 1 \mathrm{H}), 1.82-1.72(\mathrm{~m}, 1 \mathrm{H}), 1.66(\mathrm{~m}, 1 \mathrm{H}) .{ }^{13} \mathrm{C} \mathrm{NMR}\left(125 \mathrm{MHz}, \mathrm{CDCl}_{3}\right): \delta=173.03,171.02,136.71,136.68,115.79$, $115.73,67.46,67.31,62.65,62.59,60.29,60.28,54.78,36.55,36.52,33.63,33.61,28.93,28.90,25.50,25.45,25.09$, 25.05, 21.13, 21.07. HRMS-ESI $(\mathrm{m} / \mathrm{z})$ : $[\mathrm{M}+\mathrm{H}]^{+}$calculated for $\mathrm{C}_{15} \mathrm{H}_{22} \mathrm{Cl}_{2} \mathrm{O}_{5}, 353.09171$; observed, 353.09155 .

\section{8) Synthesis of compound $\mathbf{8}$}

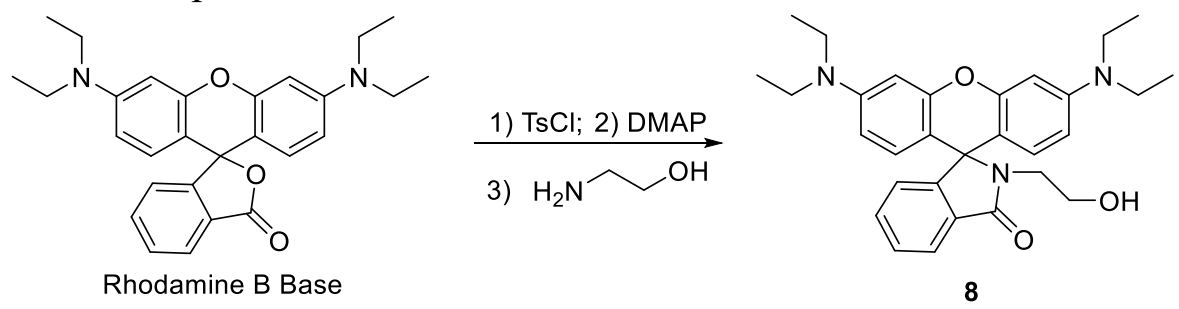

The synthetic procedure was adopted according to reported literature. ${ }^{4}$

Rhodamine B base $(2.21 \mathrm{~g}, 5 \mathrm{mmol})$ was dissolved in $20 \mathrm{~mL} \mathrm{CH} 3 \mathrm{CN}$. Tosyl chloride $(1.62 \mathrm{~g}$, $8.5 \mathrm{mmol})$ was then added to the solution and the solution was stirred for $15 \mathrm{~min}$. After DMAP $(1.40 \mathrm{~g}, 11.5 \mathrm{mmol})$ was added, the solution was stirred for additional $15 \mathrm{~min}$. A solution of enthanolamine (604 uL, $10 \mathrm{mmol})$ in $20 \mathrm{~mL} \mathrm{CH}_{3} \mathrm{CN}$ was then added. The reaction was further stirred for overnight. After the reaction completed, insoluble solid was filtered. $\mathrm{CH}_{3} \mathrm{CN}_{\text {was }}$ removed under reduced pressure and the resulting residual was dissolved with $150 \mathrm{~mL} \mathrm{Et}_{2} \mathrm{O}$. Washed with $2 \times 50 \mathrm{~mL}$ brine. After $\mathrm{Et}_{2} \mathrm{O}$ was removed, product was purified by flash chromatography ( $50 \% \mathrm{EtOAc/hexane).} \mathrm{Compound} 8$ was obtained as an off-white solid $(1.73 \mathrm{~g}, 71.5 \%) .{ }^{1} \mathrm{H}$ NMR $\left(500 \mathrm{MHz}, \mathrm{CDCl}_{3}\right): \delta 7.94-7.86(\mathrm{~m}, 1 \mathrm{H}), 7.48-7.39$ $(\mathrm{m}, 2 \mathrm{H}), 7.07(\mathrm{~m}, 1 \mathrm{H}), 6.49(\mathrm{~d}, J=8.8 \mathrm{~Hz}, 2 \mathrm{H}), 6.38(\mathrm{~d}, J=2.6 \mathrm{~Hz}, 2 \mathrm{H}), 6.29(\mathrm{dd}, J=8.9,2.6 \mathrm{~Hz}, 2 \mathrm{H}), 4.21-4.13$ $(\mathrm{m}, 1 \mathrm{H}), 3.47(\mathrm{q}, J=5.2 \mathrm{~Hz}, 2 \mathrm{H}), 3.33(\mathrm{q}, J=7.1 \mathrm{~Hz}, 8 \mathrm{H}), 3.30-3.24(\mathrm{t}, J=4.9 \mathrm{~Hz}, 2 \mathrm{H}), 1.16(\mathrm{t}, J=7.0 \mathrm{~Hz}, 12 \mathrm{H})$. ${ }^{13} \mathrm{C}$ NMR $\left(125 \mathrm{MHz}, \mathrm{CDCl}_{3}\right): \delta 170.23,154.04,153.39,149.01,132.82,130.56,128.63,128.26,123.93,123.03$, 108.35, 104.90, 97.90, 66.00, 62.83, 62.82, 44.79, 44.49, 12.72. HRMS-ESI $(m / z):[\mathrm{M}+\mathrm{H}]^{+}$calculated for $\mathrm{C}_{30} \mathrm{H}_{35} \mathrm{~N}_{3} \mathrm{O}_{3}$, 486.27512; observed, 486.27573 .

9) Synthesis of compound 9
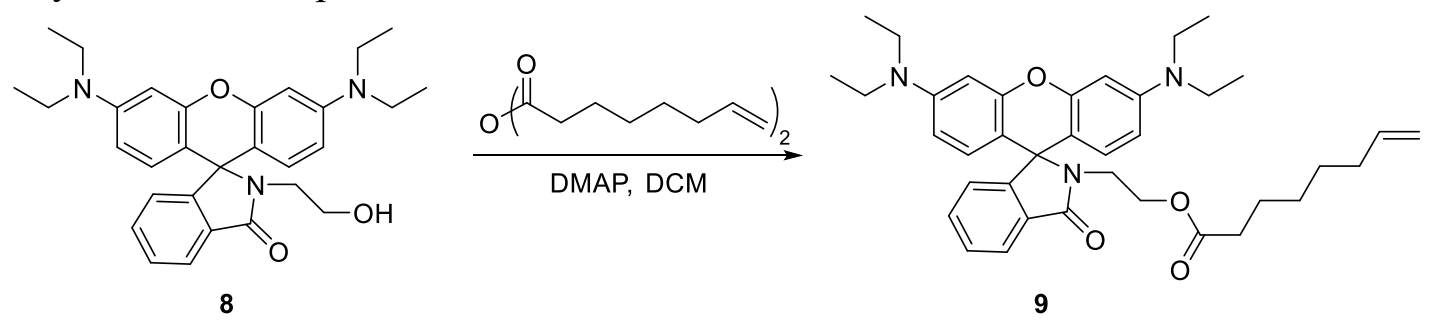
7-Octenoic anhydride was prepared using adopted procedures from previous paper. ${ }^{5}$ To a solution of 7-Octanoic acid $(1.54 \mathrm{~mL}, 10 \mathrm{mmol})$ in $25 \mathrm{ml} \mathrm{DCM}$, added $\mathrm{N}$, N'-dicyclohexylcarbodiimide (1.07 g, $5.2 \mathrm{mmol})$. The reaction was stirred overnight and the resulting insoluble solid was filtered. DCM was removed and $30 \mathrm{~mL}$ hexane was added to dissolve the residual. Insoluble solid was further filtered and collected filtrate was condensed under reduced pressure. The resulting liquid was used without further purification.

To a $20 \mathrm{~mL}$ scintillation vial, compound 7 ( $485 \mathrm{mg}, 1 \mathrm{mmol})$ and DMAP $(12 \mathrm{mg}, 0.1 \mathrm{mmol})$ were dissolved with 10 $\mathrm{mL}$ THF. Octanoic anhydride (319 mg, $1.2 \mathrm{mmol}$ ) was then added dropwise. After the reaction was stirred overnight, solvent was removed and the residual was subjected to flash chromatography to give compound $\mathbf{9}$ as a white solid (600 mg, 95.8\%). ${ }^{1} \mathrm{H}$ NMR (500 MHz, $\left.\mathrm{CDCl}_{3}\right): \delta 7.94-7.85(\mathrm{~m}, 1 \mathrm{H}), 7.46-7.38(\mathrm{~m}, 2 \mathrm{H}), 7.11-7.00(\mathrm{~m}, 1 \mathrm{H}), 6.45$ $(\mathrm{d}, J=8.8 \mathrm{~Hz}, 2 \mathrm{H}), 6.38(\mathrm{~d}, J=2.6 \mathrm{~Hz}, 2 \mathrm{H}), 6.26(\mathrm{dd}, J=8.9,2.6 \mathrm{~Hz}, 2 \mathrm{H}), 5.77$ (ddt, $J=17.0,10.2,6.7 \mathrm{~Hz}, 1 \mathrm{H})$, $5.02-4.87(\mathrm{~m}, 2 \mathrm{H}), 3.80$ (t, $J=6.4 \mathrm{~Hz}, 2 \mathrm{H}), 3.40$ (t, $J=6.4 \mathrm{~Hz}, 2 \mathrm{H}), 3.33(\mathrm{q}, J=7.1 \mathrm{~Hz}, 8 \mathrm{H}), 2.11(\mathrm{t}, J=7.6 \mathrm{~Hz}$, 2H), $2.01(\mathrm{q}, J=7.1 \mathrm{~Hz}, 2 \mathrm{H}), 1.51(\mathrm{p}, J=7.6 \mathrm{~Hz}, 2 \mathrm{H}), 1.35(\mathrm{p}, J=7.2 \mathrm{~Hz}, 2 \mathrm{H}), 1.29-1.21(\mathrm{~m}, 2 \mathrm{H}), 1.16(\mathrm{t}, J=7.1$ $\mathrm{Hz}, 12 \mathrm{H}) .{ }^{13} \mathrm{C}$ NMR $\left(125 \mathrm{MHz}, \mathrm{CDCl}_{3}\right): \delta 173.41,168.68,154.06,153.36,148.93,139.00,132.61,130.79,128.94$, 128.09, 123.93, 122.97, 114.48, 108.25, 105.54, 97.88, 64.98, 61.56, 44.48, 39.11, 34.08, 33.70, 28.72, 28.69, 24.73, 12.75. HRMS-ESI $(\mathrm{m} / \mathrm{z})$ : $[\mathrm{M}+\mathrm{H}]^{+}$calculated for $\mathrm{C}_{38} \mathrm{H}_{47} \mathrm{~N}_{3} \mathrm{O}_{4}, 610.36393$; observed, 610.36461 .

\section{Synthesis of ROMP polymers}

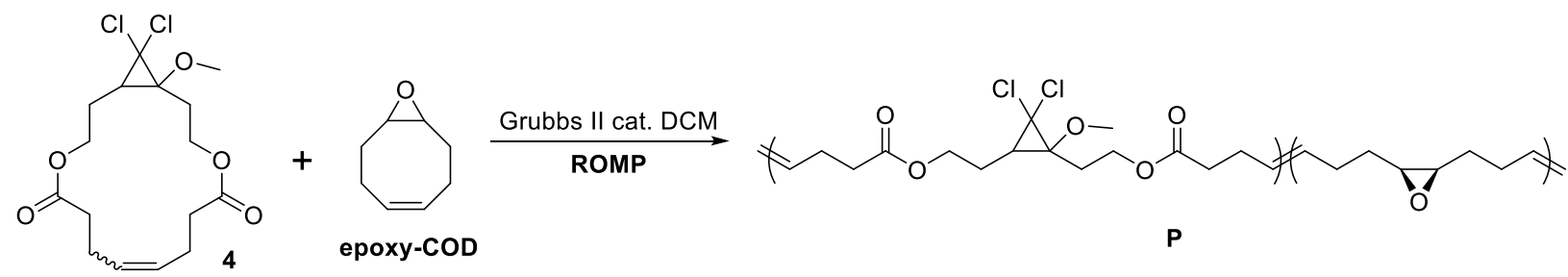

In a $5 \mathrm{~mL}$ frame dried scintillation via, added compound $4(36.5 \mathrm{mg}, 0.1 \mathrm{mmol})$ and epoxy-COD $(12.4 \mathrm{mg}, 0.1 \mathrm{mmol})$. The vial was kept under Ar. To another frame dried scintillation vial, added Grubbs II catalyst $\left(1.4 \mathrm{mg}, 1.67 \times 10^{-3}\right.$ mmol). $2 \mathrm{~mL}$ dry DCM was added to dissolve the catalyst and the resulting solution was bubbled with Ar for 3 min. $0.2 \mathrm{~mL}$ of the catalyst solution $\left(0.14 \mathrm{mg}, 1.67 \times 10^{-3} \mathrm{mmol}\right)$ was then added to the monomer containing vial. The via was then sealed and stirred for overnight. Several drops of ethyl vinyl ether were added to quench the polymerization. The viscous solution was further stirred for $30 \mathrm{~min}$. A white polymer was obtained after three times precipitation from $\mathrm{MeOH}$. The polymer was then dissolved in $2 \mathrm{~mL} \mathrm{DCM}, \mathrm{MeOH}$ was slowly added to the solution until the solution turned cloudy. The cloudy suspension was then subjected to centrifuge to separate out a thin layer of polymer at the bottom of the vial. This polymer was collected and further dried under high vacuum and used for single molecule force spectroscopy test. The molar content of compound 4 was determined to be $47 \%$ from ${ }^{1} \mathrm{H}$ NMR.

\section{Preparation of PDMS materials}

To a $10 \mathrm{~mL}$ scintillation vial, added the following small molecules for each sample.

Active: mechanophore 3 (11 mg, $0.5 \mathrm{wt} \%)$ and rhodamine 9 (1.7 $\mathrm{mg}, 10 \mathrm{~mol} \%$ of $\mathbf{3})$

Control 1: rhodamine $9(1.7 \mathrm{mg})$

Control 2: control mechanophore 7 (11 mg, $0.5 \mathrm{wt} \%)$ and rhodamine $9(1.7 \mathrm{mg}, 10 \mathrm{~mol} \%$ of 3)

$250 \mu \mathrm{L}$ xylene was then added to the vial to dissolve the small molecule. Sylgard ${ }^{\circledR} 184$ PDMS base part $(2.0 \mathrm{~g})$ was added and mixed completely using Vortex. PDMS curing $(0.2 \mathrm{~g})$ was then added and further mixed to give a clear mixture and it turned pale pink after a few minutes. This viscous mixture was then degassed and cast on a PP board or a PS dish. Curing at $65{ }^{\circ} \mathrm{C}$ for overnight gave a pale pink clear pale-pink material. The pale-pink background color is due to the platinum catalyst induced ring opening of rhodamine dye. 


\section{Thermal stability of mehcanoacid}

In a dried NMR tube, $\sim 5 \mathrm{mg}$ of compound 5 was dissolved with $0.5 \mathrm{ml}$ toluene- $d_{6}$. The NMR tube was then sealed and heated at $110^{\circ} \mathrm{C}$ for $0 \mathrm{~h}, 2 \mathrm{~h}, 4 \mathrm{~h}$ and $25.5 \mathrm{~h}$. ${ }^{1} \mathrm{H}$ NMR spectroscopy was collected at each time point. No thermally activated ring-opening product was observed even after $25.5 \mathrm{~h}$.

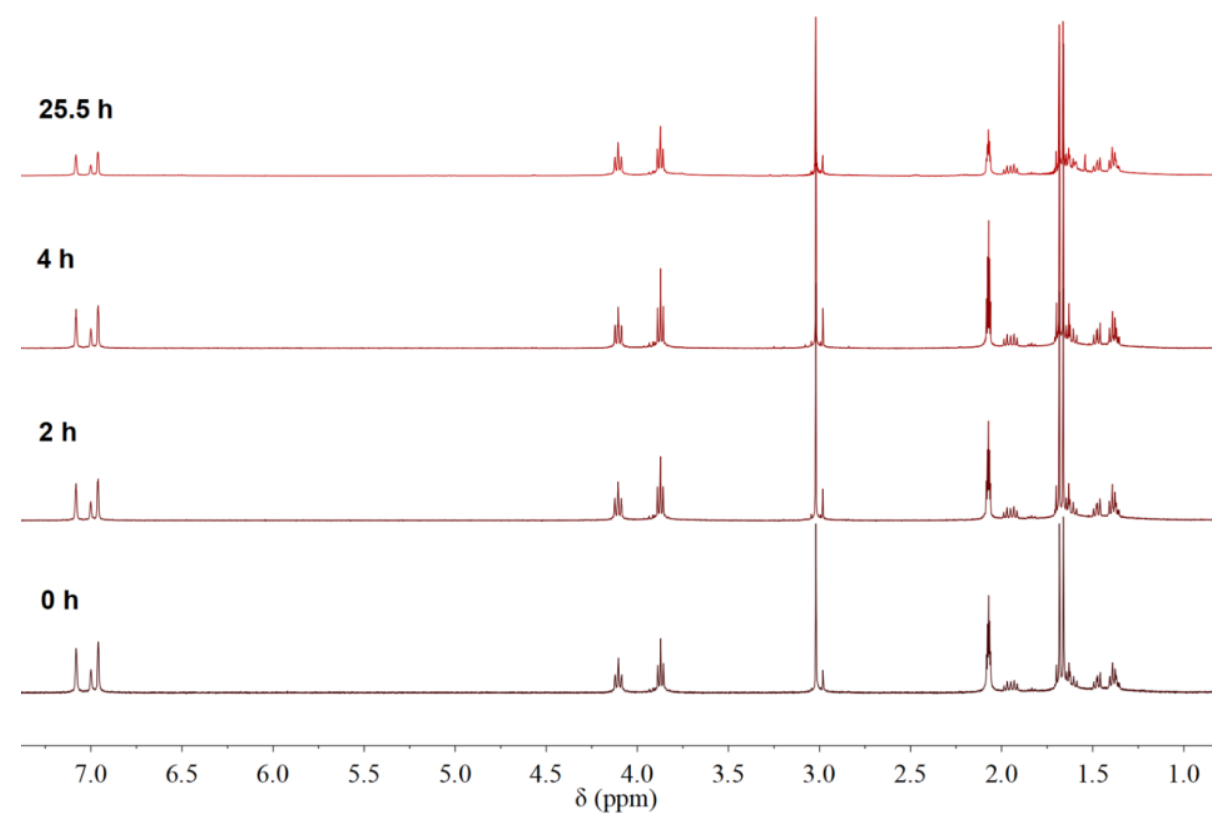

Figure S1. Thermal stability test: ${ }^{1} \mathrm{H}$ NMR of compound $\mathbf{5}$ in toluene- $d_{6}$ heated at $110{ }^{\circ} \mathrm{C}$ for different periods of time.

To a $25 \mathrm{~mL}$ dried Schlenk flask, added $100 \mathrm{mg}$ compound 5 and $0.5 \mathrm{~mL}$ of diphenyl ether. The flask was heated at $138^{\circ} \mathrm{C}$ under $\mathrm{N}_{2}$. Aliquot of $20 \mu \mathrm{L}$ solution was taken out for ${ }^{1} \mathrm{H}$ NMR analysis at each time point $(0,1,2,3,5 \mathrm{~h})$.

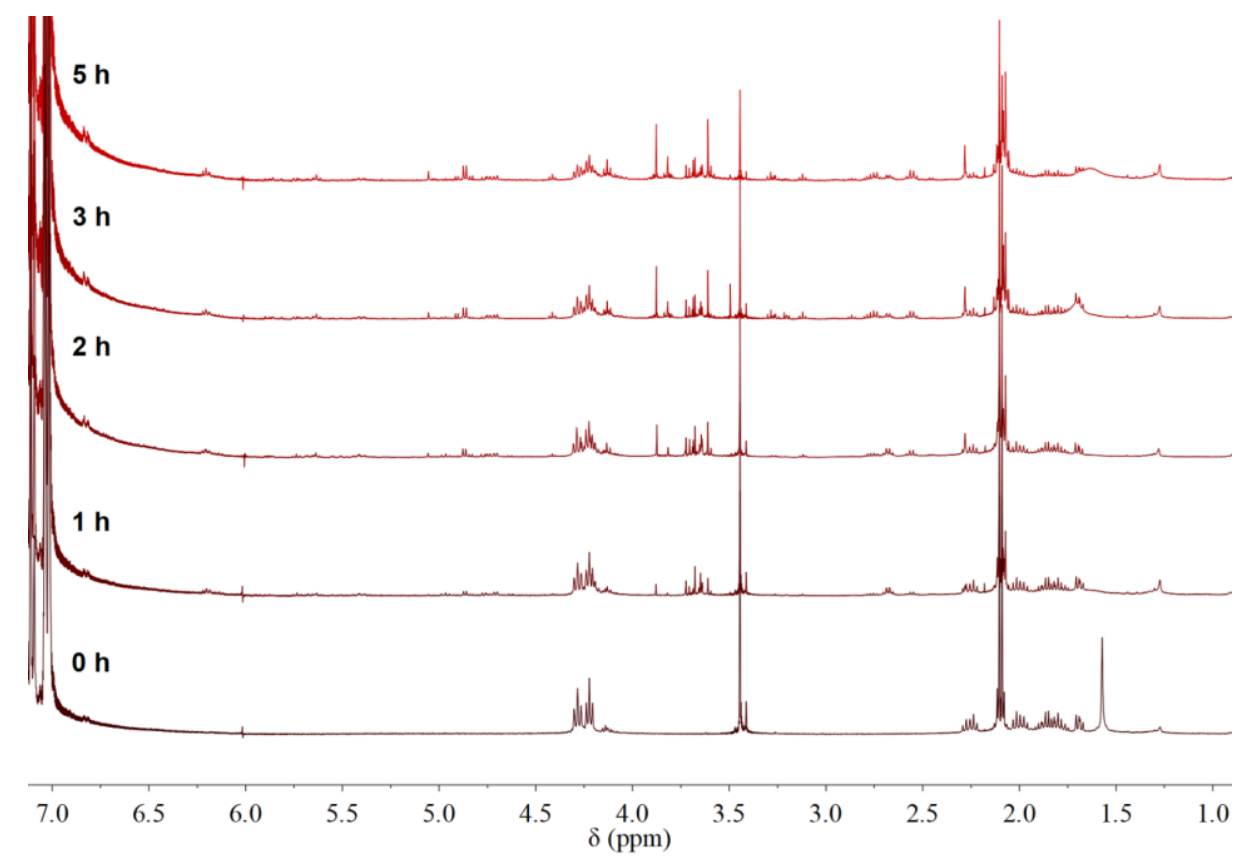

Figure S2. New species appeared after thermolysis of compound $\mathbf{5}$ in diphenyl ether at $138.5 \pm 0.5{ }^{\circ} \mathrm{C}$. 


\section{Sonication experiment}

\section{Study of mechanophore activation under sonication}

A solution of $32 \mathrm{mg}$ polymer $\mathbf{P}$ in $16 \mathrm{~mL}$ dry THF was transferred to a Suslick cell. The solution was cooled with an ice bath and bubbled with $\mathrm{N}_{2}$ for 5 min. Sonication was performed with a Sonics VC750 at $30 \%$ amplitude (1s on, $1 \mathrm{~s}$ off) under ice bath. Aliquots of $0.9 \mathrm{ml}$ solution at each time point $(0,15,30,60,120,180,240 \mathrm{~min})$ were taken out from the cell and subjected to GPC-MALS analysis. Remained solution samples were condensend and the resulting thin layer of polymer was rinsed with $\mathrm{MeOH}$ twice to remove byproduct from sonication. The obtained polymer was further dried under high vacuum and analyzed from ${ }^{1} \mathrm{H}$ NMR.

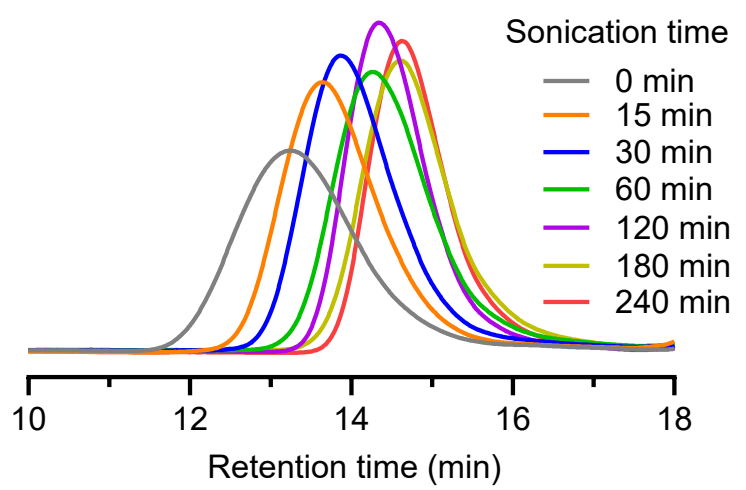

Figure S3. Primary GPC elugrams of polymer $\mathbf{P}$ as a function of sonication time. Molecular weights obtained by static light scattering are provided in Figure $2 b$.

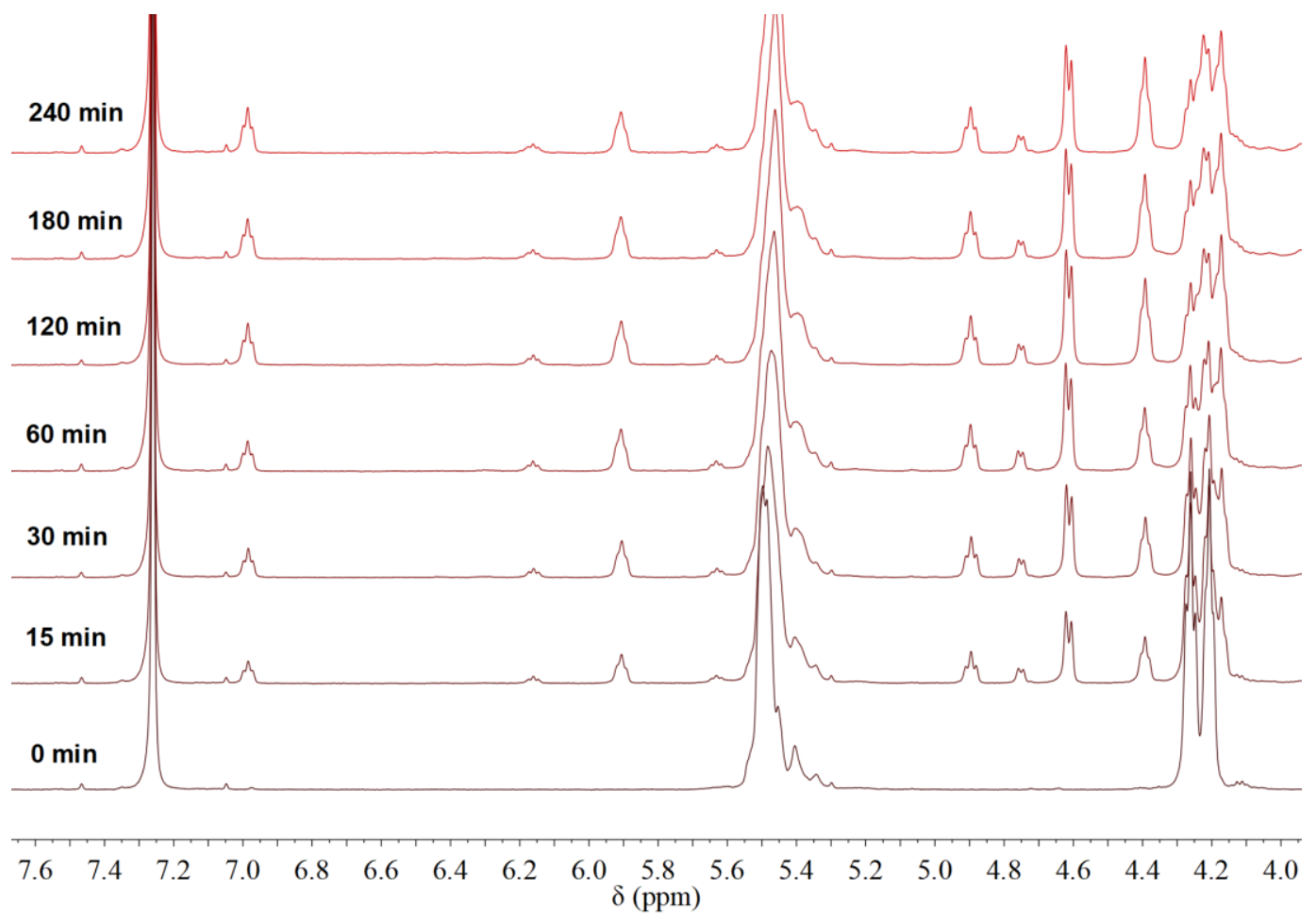

Figure S4. Overlay of ${ }^{1} \mathrm{H}$ NMR $\left(\mathrm{CDCl}_{3}, 500 \mathrm{MHz}\right)$ spectra of sonicated polymer $\mathbf{P}$ at various sonication times. 


\section{Probing mechanoacid}

A solution of $42 \mathrm{mg}$ polymer $\mathbf{P}$ in $21 \mathrm{~mL}$ dry THF $(2 \mathrm{mg} / \mathrm{mL})$ was transferred to a Suslick cell. The solution was cooled and bubbled with $\mathrm{N}_{2}$ for $5 \mathrm{~min}$. Pulsed ultrasound was then applied ( $30 \%$ amplitude, $1 \mathrm{~s}$ on $/ 1 \mathrm{~s}$ off). Aliquots of $1.0 \mathrm{~mL}$ solution at each time point $(0,15,30,60,120,180,240 \mathrm{~min})$ was taken out from the cell. A solution of $38 \mathrm{mg}$ Rhodamine B base in $21 \mathrm{~mL}$ dry THF was prepared. $0.1 \mathrm{~mL}$ sonicated solution and $0.9 \mathrm{~mL}$ rhodamine solution were then mixed to give a solution with $0.1 \mathrm{mg} / \mathrm{mL}$ polymer $\mathbf{P}$ and $0.09 \mathrm{mg} / \mathrm{mL}$ rhodamine $\mathrm{B}$ base. The sonicated solution turned pink instantly upon adding rhodamine solution. These samples were further subjected to UV-vis analysis.

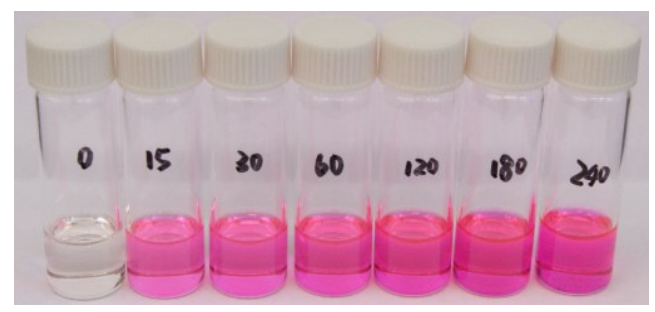

Figure S5. Polymer $\mathbf{P}$ solution was subjected to sonication for various times $(0,15,30,60,120,180,240 \mathrm{~min})$ and added with rhodamine B base solution. (The pink color appeared instantly after adding rhodamine B base solution.)

a)

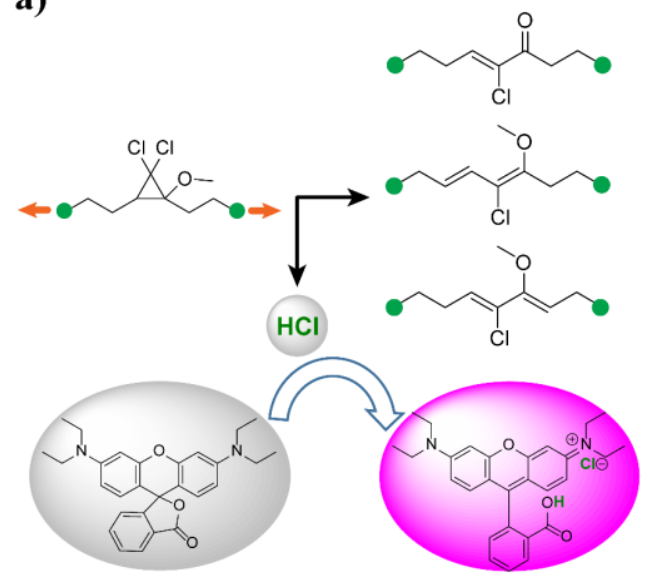

b)

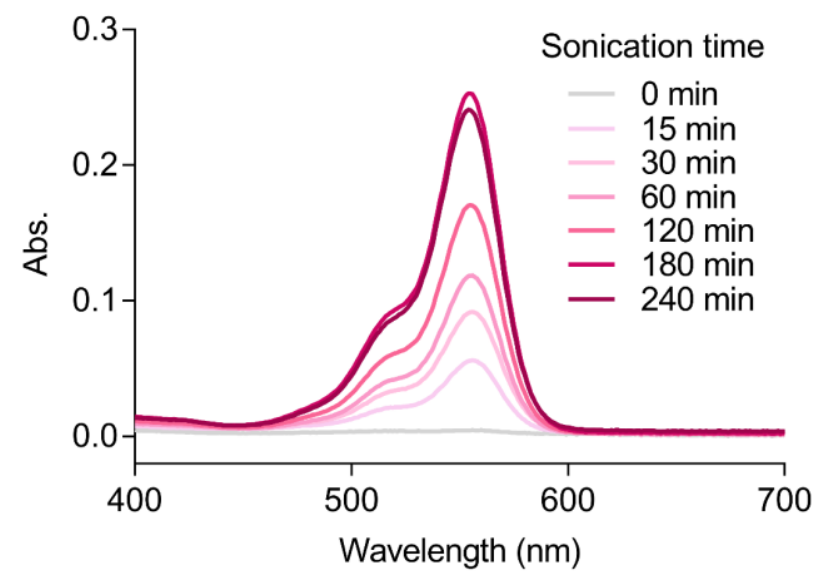

Figure S6. a) Schematic protonation of rhodamine by generated mechanoacid. b) UV-vis spectra of sonicated polymer solution with rhodamine dye at various sonication times.

\section{SMFS analysis}

\section{Calculation of transition state}

We calculated the transition state of ring opening reaction for parent $g \mathrm{DCC}$ and MeO-gDCC using GaussView 5.0.9 software. The ground state and ring-opened product of parent $g \mathrm{DCC}$ and $\mathrm{MeO}-\mathrm{gDCC}$ were first optimized using DFT method on the theory level of B3YLP/61G*(d). The transition state of each was then calculated on the same theory level using QST3 method with force constant calculated for once. 


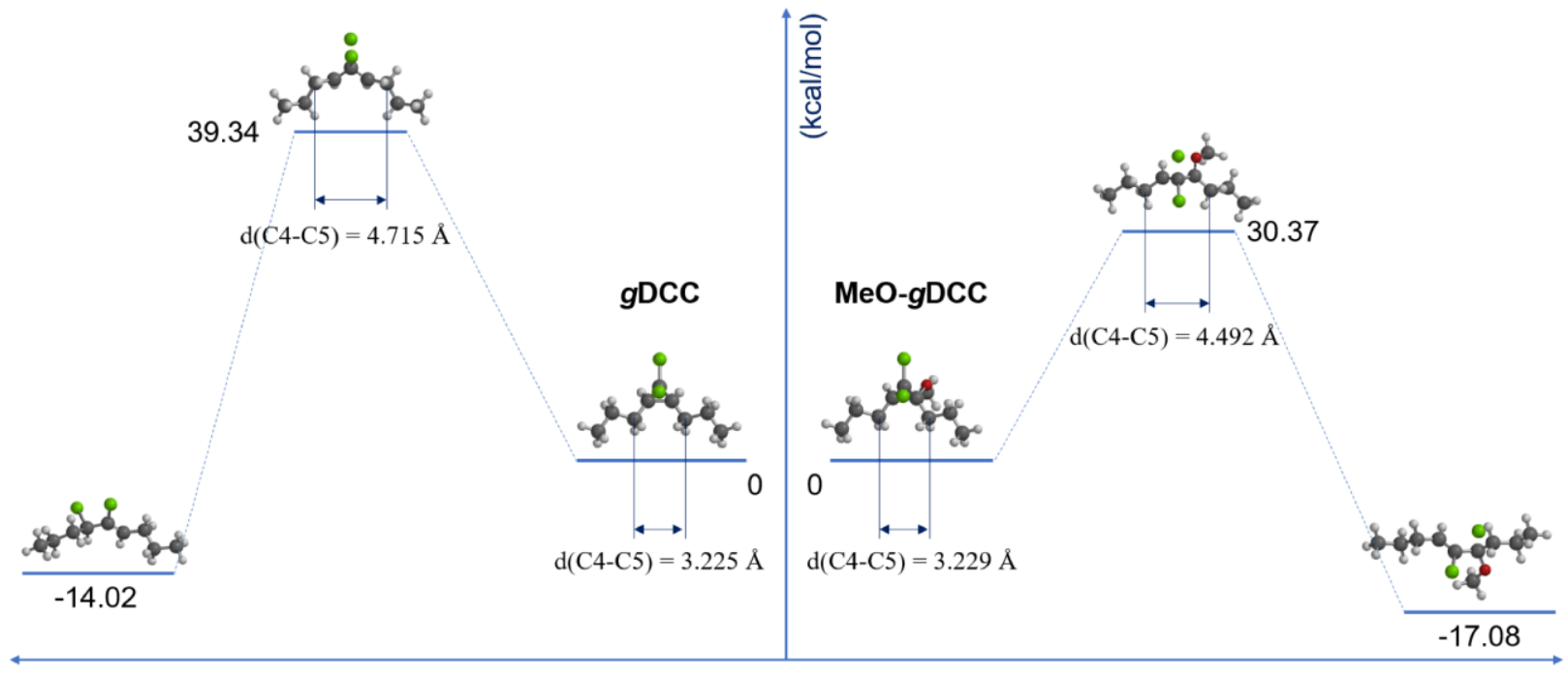

Figure S7. Calculation of transition state for $g \mathrm{DCC}$ and $\mathrm{MeO}-\mathrm{gDCC}$. The activation energy of MeO-gDCC is $\sim 9$ $\mathrm{kcal} / \mathrm{mol}$ less than that of $g \mathrm{DCC}$. The absolute mechanical coupling of the reaction should take into account the effects of connection to the polymer chain, but the relative mechanical coupling of the two systems is roughly estimated by the distance changes shown: $\Delta x^{\ddagger}(g D C C)=4.715-3.225=1.49 \AA, \Delta x^{\ddagger}(\mathrm{MeO}-g \mathrm{DCC})=4.492-3.229=1.263 \AA$. Thus the $\Delta \Delta x^{\ddagger}$ of MeO-gDCC vs. $g \mathrm{DCC}$ is $\sim(1.49 \AA-1.26)=0.23 \AA$, consistent with the difference derived from SMFS curve fitting.

\section{SMFS curve analysis}

Force-extension curves were analyzed using method reported in previous literature. ${ }^{1-2}$ Pre- and post-transition force curves were fitted with an extended freely jointed chain (FJC) model to give the contour lengths of polymers before and after transition. Further analysis with a Cusp models provided mechanical coupling $(\Delta x)$ information.

1) SMFS curve fitting
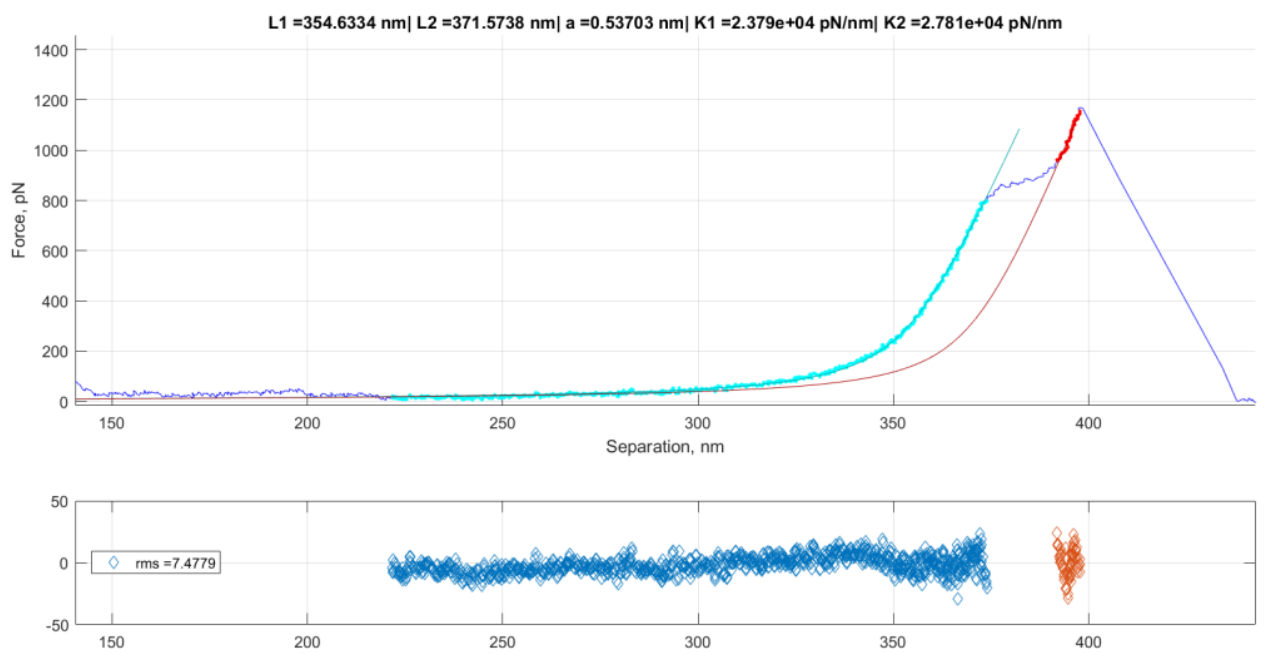

Figure S8. Representative fitting of pre- and post-transition curves using an extended-FJC model. 

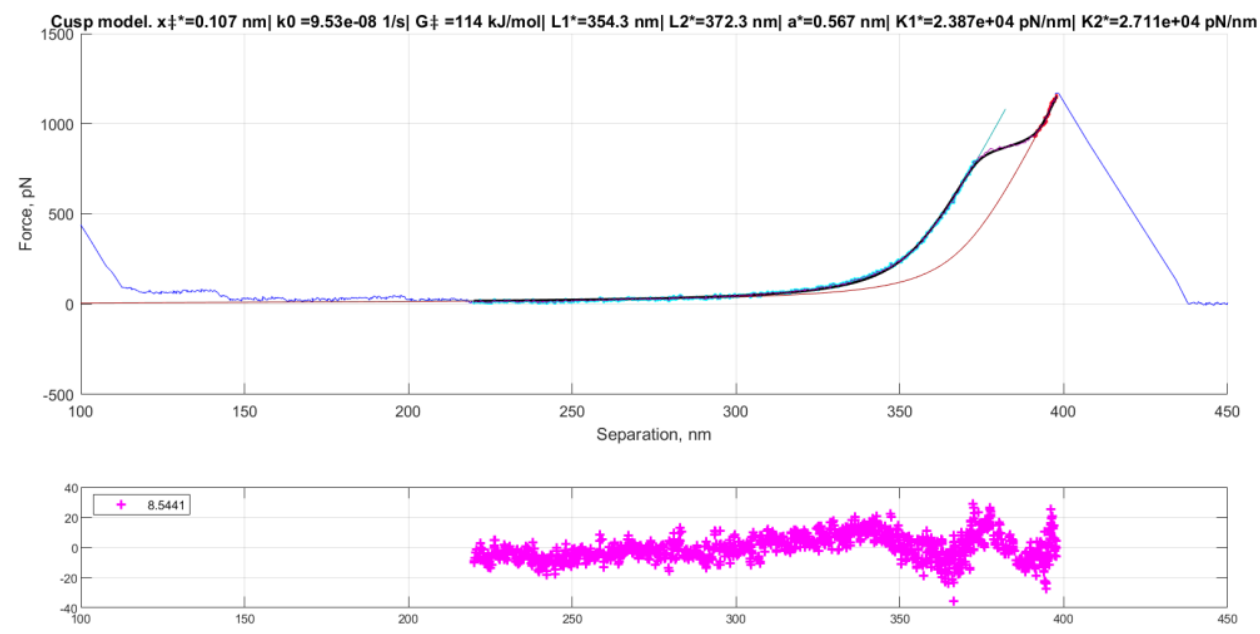

Figure S9. Representative fitting of SMFS curve using a Cusp model. The mechanical coupling was retrieved: $\Delta x^{\sharp}=$ $1.07 \AA$.

The characteristic transition force was determined by deriving the first and second derivative of force-extension curves. The characteristic force point on the plateau corresponds to the zero point in the second derivative and minimum point in the first derivative.

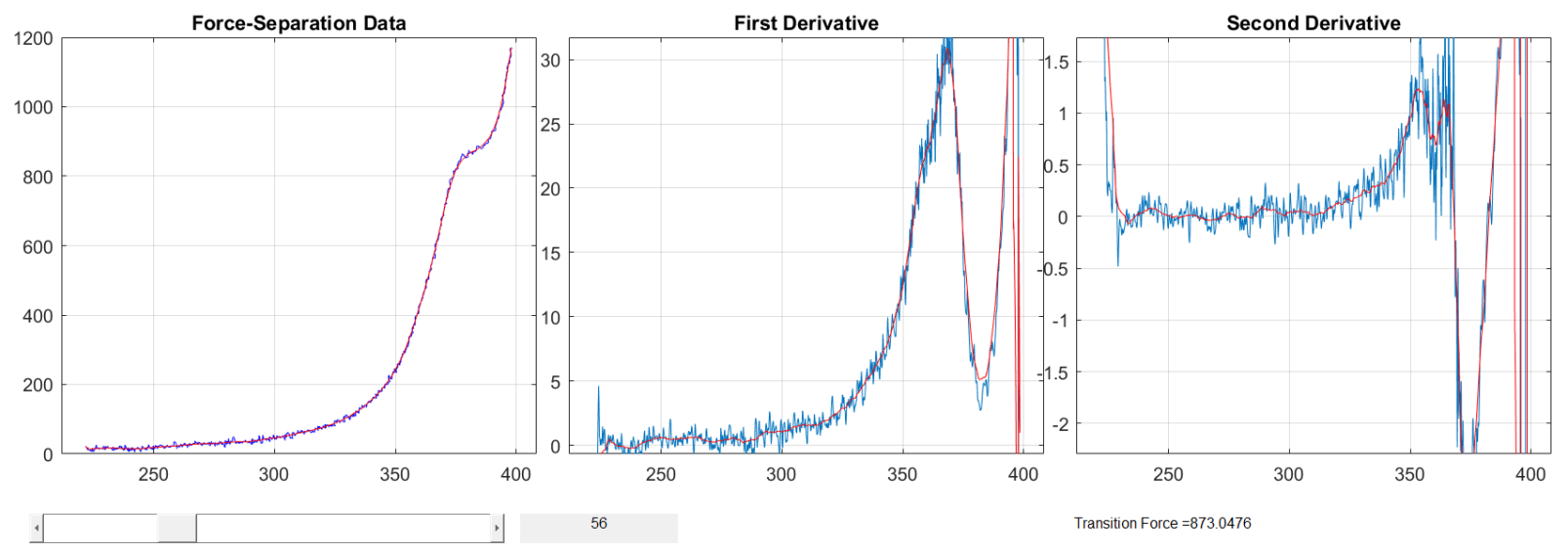

Figure S10. Determination of characteristic transition force using first and second derivative of SMFS curve.

\section{2) Additional SMFS curves}



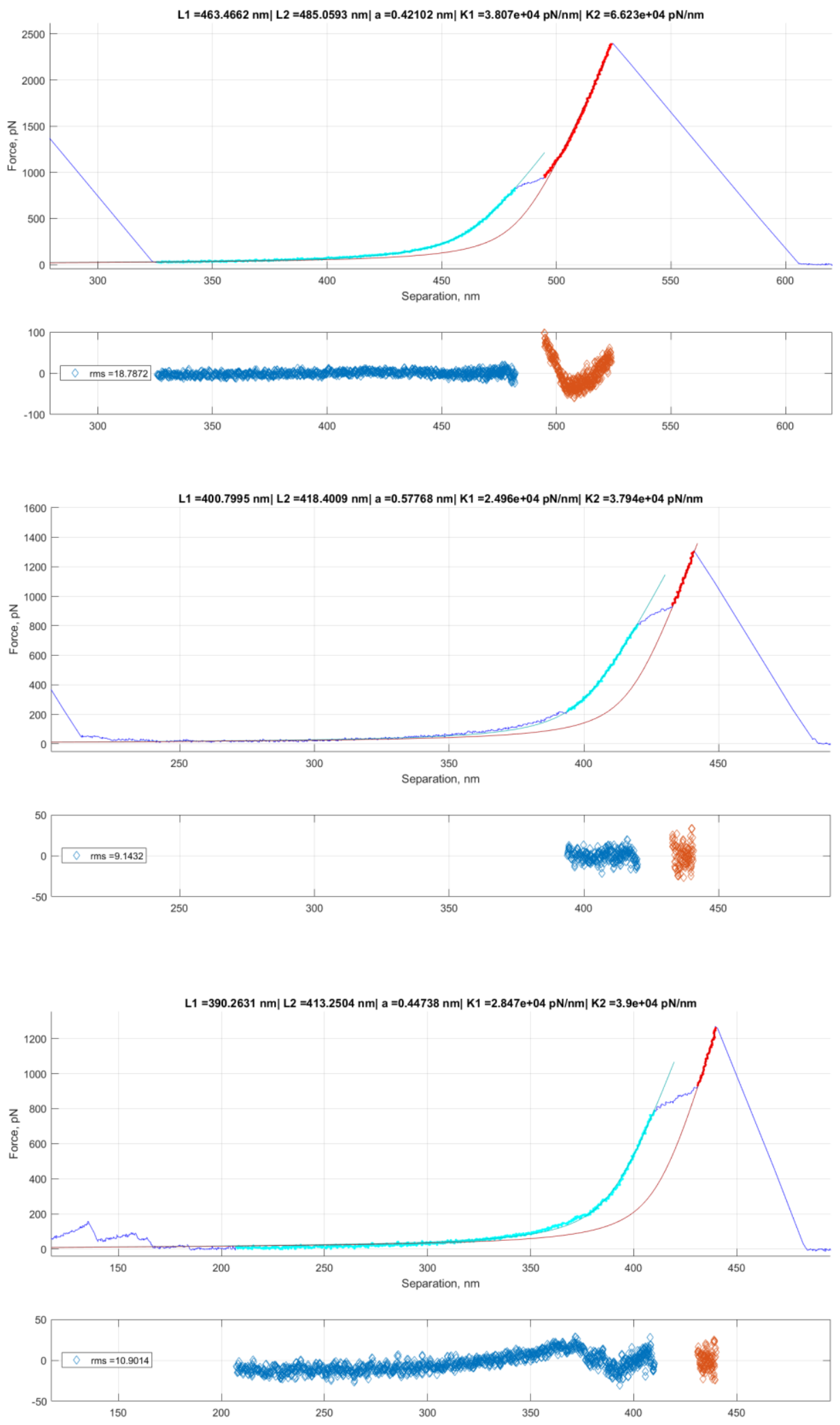

S14 

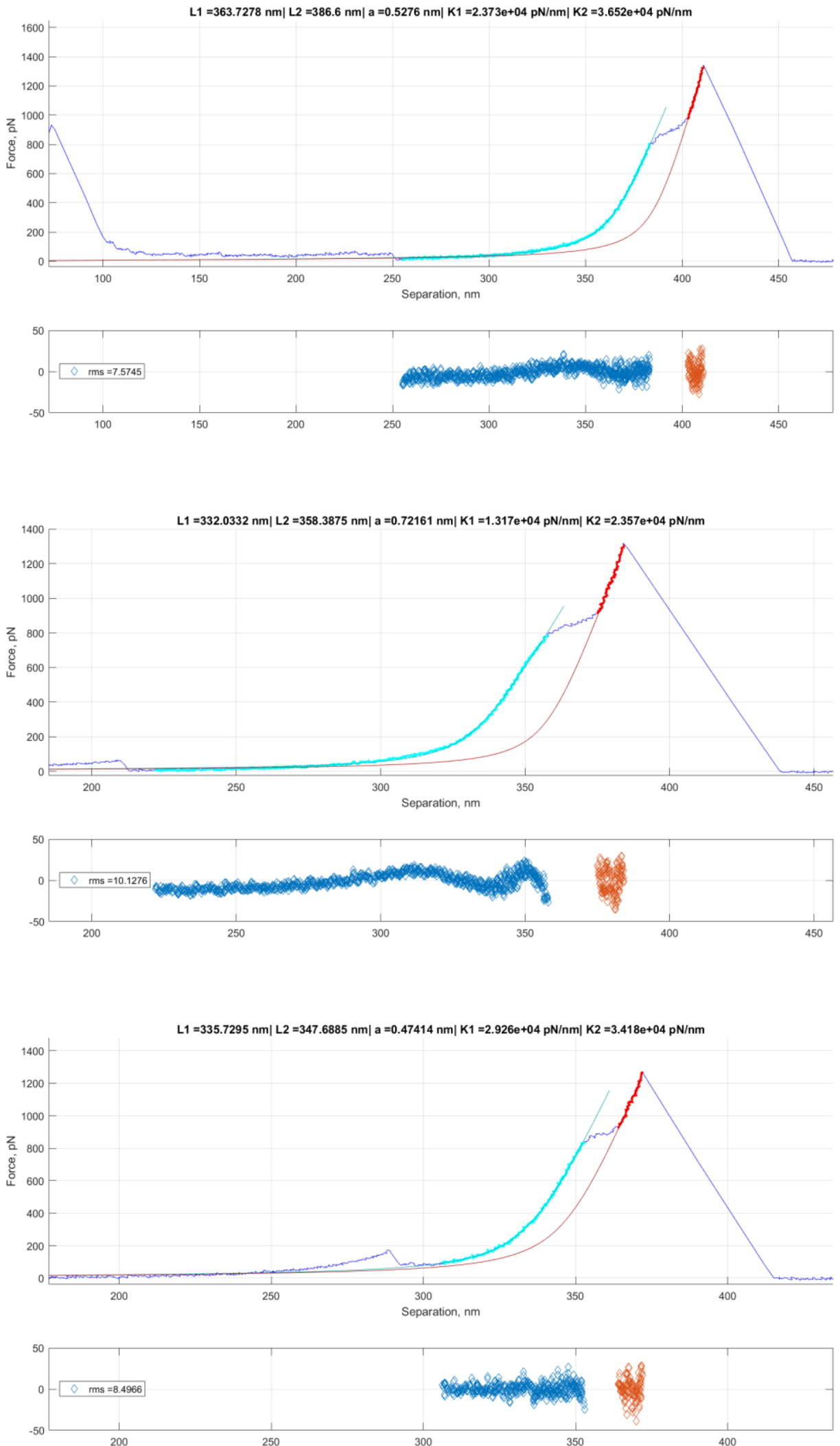
3) SMFS data list

Table S1. List of results from SMFS curves analysis

\begin{tabular}{|c|c|c|c|c|c|c|c|c|}
\hline \multirow{2}{*}{ \# } & \multirow{2}{*}{$\mathrm{L}_{i}(\mathrm{~nm})$} & \multirow{2}{*}{$\mathrm{L}_{f}(\mathrm{~nm})$} & \multirow{2}{*}{$\mathrm{L}_{f} / \mathrm{L}_{i}$} & \multirow{2}{*}{$\begin{array}{l}\text { Kuhn } \\
\text { length } \\
(\mathrm{nm})\end{array}$} & \multirow{2}{*}{$\begin{array}{c}\mathrm{K}_{1} \\
(\mathrm{pN} / \mathrm{nm})\end{array}$} & \multirow{2}{*}{$\begin{array}{c}\mathrm{K}_{2} \\
(\mathrm{pN} / \mathrm{nm})\end{array}$} & $\Delta \mathrm{x}^{\ddagger}(\AA)$ & \multirow{2}{*}{$f^{*}(\mathrm{pN})$} \\
\hline & & & & & & & Cusp & \\
\hline 1 & 332.0 & 358.4 & 1.079 & 0.722 & $1.3 \mathrm{E}+04$ & $2.4 \mathrm{E}+04$ & 1.09 & 850 \\
\hline 2 & 134.3 & 143.8 & 1.071 & 0.565 & $1.7 \mathrm{E}+04$ & $2.7 \mathrm{E}+04$ & 1.07 & 850 \\
\hline 3 & 162.7 & 166.2 & 1.021 & 0.625 & $1.3 \mathrm{E}+04$ & $1.1 \mathrm{E}+04$ & 1.11 & 864 \\
\hline 4 & 179.2 & 187.8 & 1.048 & 0.569 & $2.7 \mathrm{E}+04$ & $3.3 \mathrm{E}+04$ & 1.08 & 872 \\
\hline 5 & 166.0 & 179.3 & 1.080 & 0.763 & $1.8 \mathrm{E}+04$ & $4.8 \mathrm{E}+04$ & 1.09 & 853 \\
\hline 6 & 188.2 & 198.2 & 1.053 & 0.542 & $1.9 \mathrm{E}+04$ & $2.4 \mathrm{E}+04$ & 1.08 & 878 \\
\hline 7 & 224.0 & 232.8 & 1.039 & 0.575 & $2.2 \mathrm{E}+04$ & $2.2 \mathrm{E}+04$ & 1.07 & 870 \\
\hline 8 & 234.6 & 254.5 & 1.085 & 0.721 & $1.5 \mathrm{E}+04$ & $3.4 \mathrm{E}+04$ & 1.05 & 852 \\
\hline 9 & 133.5 & 145.1 & 1.087 & 0.568 & $2.0 \mathrm{E}+04$ & $5.1 \mathrm{E}+04$ & 1.07 & 888 \\
\hline 10 & 240.9 & 260.6 & 1.082 & 0.518 & $2.4 \mathrm{E}+04$ & $5.6 \mathrm{E}+04$ & 1.05 & 875 \\
\hline 11 & 377.5 & 406.9 & 1.078 & 0.505 & $2.6 \mathrm{E}+04$ & $5.1 \mathrm{E}+04$ & 1.05 & 910 \\
\hline 12 & 195.1 & 206.7 & 1.060 & 0.457 & $3.3 \mathrm{E}+04$ & $4.6 \mathrm{E}+04$ & 1.05 & 905 \\
\hline 13 & 340.5 & 360.6 & 1.059 & 0.536 & $2.6 \mathrm{E}+04$ & $3.5 \mathrm{E}+04$ & 1.05 & 888 \\
\hline 14 & 390.3 & 413.3 & 1.059 & 0.447 & $2.8 \mathrm{E}+04$ & $3.9 \mathrm{E}+04$ & 1.08 & 856 \\
\hline 15 & 472.1 & 490.5 & 1.039 & 0.385 & $4.6 \mathrm{E}+04$ & $6.5 \mathrm{E}+04$ & 1.06 & 869 \\
\hline 16 & 185.4 & 193.4 & 1.043 & 0.485 & $2.6 \mathrm{E}+04$ & $2.9 \mathrm{E}+04$ & 1.01 & 890 \\
\hline 17 & 335.7 & 347.7 & 1.036 & 0.474 & $2.9 \mathrm{E}+04$ & $3.4 \mathrm{E}+04$ & 1.07 & 885 \\
\hline 18 & 354.6 & 371.6 & 1.048 & 0.537 & $2.4 \mathrm{E}+04$ & $2.9 \mathrm{E}+04$ & 1.07 & 873 \\
\hline 19 & 463.5 & 485.1 & 1.047 & 0.421 & $3.8 \mathrm{E}+04$ & $6.6 \mathrm{E}+04$ & 1.02 & 882 \\
\hline 20 & 268.2 & 284.1 & 1.059 & 0.409 & $3.6 \mathrm{E}+04$ & $5.1 \mathrm{E}+04$ & 1.07 & 880 \\
\hline 21 & 527.9 & 548.9 & 1.040 & 0.544 & $2.4 \mathrm{E}+04$ & $2.8 \mathrm{E}+04$ & 1.07 & 870 \\
\hline 22 & 152.4 & 159.8 & 1.049 & 0.381 & $3.6 \mathrm{E}+04$ & $4.0 \mathrm{E}+04$ & 1.06 & 912 \\
\hline 23 & 400.8 & 418.4 & 1.044 & 0.578 & $2.5 \mathrm{E}+04$ & $3.8 \mathrm{E}+04$ & 1.08 & 888 \\
\hline 24 & 363.7 & 386.6 & 1.063 & 0.528 & $2.4 \mathrm{E}+04$ & $3.7 \mathrm{E}+04$ & 1.05 & 886 \\
\hline 25 & 189.3 & 200.4 & 1.059 & 0.461 & $7.7 \mathrm{E}+03$ & $9.8 \mathrm{E}+03$ & 1.07 & 890 \\
\hline \multirow{2}{*}{$\begin{array}{l}\text { Avg. } \\
\text { SD. }\end{array}$} & \multirow{2}{*}{ I } & \multirow{2}{*}{ I } & 1.057 & \multirow{2}{*}{ I } & \multirow{2}{*}{ / } & \multirow{2}{*}{ / } & 1.068 & 877 \\
\hline & & & 0.018 & & & & 0.023 & 18 \\
\hline Report & I & I & $\begin{array}{r}1.06 \\
\pm 0.02 \\
\end{array}$ & I & / & / & $\begin{array}{r}\mathbf{1 . 0 7} \\
\pm \mathbf{0 . 0 2} \\
\end{array}$ & $\begin{array}{r}880 \\
\pm 20 \\
\end{array}$ \\
\hline
\end{tabular}

\section{4) Relative reaction rate}

The Arrhenius equation modified by Bell ${ }^{6}$ provides the following rate-force relation:

$$
k(F)=A e^{\frac{F \Delta x^{\ddagger}-\Delta G^{\ddagger} / N_{A}}{k_{B} T}}
$$

The relative ring-opening rate of $\mathrm{MeO}-g \mathrm{DCC}$ to $g \mathrm{DCC}$ at force of $880 \mathrm{pN}$ can be calculated:

$$
\frac{k(M e O-g D C C)}{k(g D C C)}=e^{\frac{F \Delta \Delta x^{\ddagger}-\Delta \Delta G^{\ddagger} / N_{A}}{k_{B} T}}=e^{\frac{880 *(1.07-1.28) * 10^{-22}-(27.2-36.2) * 4184 /\left(6.02 * 10^{23}\right)}{1.38 * 10^{-23 * 298}}}=2,647,165=\sim 10^{6}
$$




\section{Generation and labeling of mechanoacid in PDMS elastomer}

\section{Mechanical activation of mechanoacid}

Qualitative evaluation of mechanoacid activation in PDMS elastomer was performed by stretch, compression, and localized compression.

Prepared PDMS elastomer film is about $0.3 \sim 0.4 \mathrm{~mm}$ in thickness. The film was manually stretched to near maximum strain and relaxed. For PDMS cylinders, the thickness is around $\sim 0.3 \mathrm{~cm}$. The cylinder was applied with a hammer strike. In turns of localized compression, the cylinder was manually compressed with an iron rod.

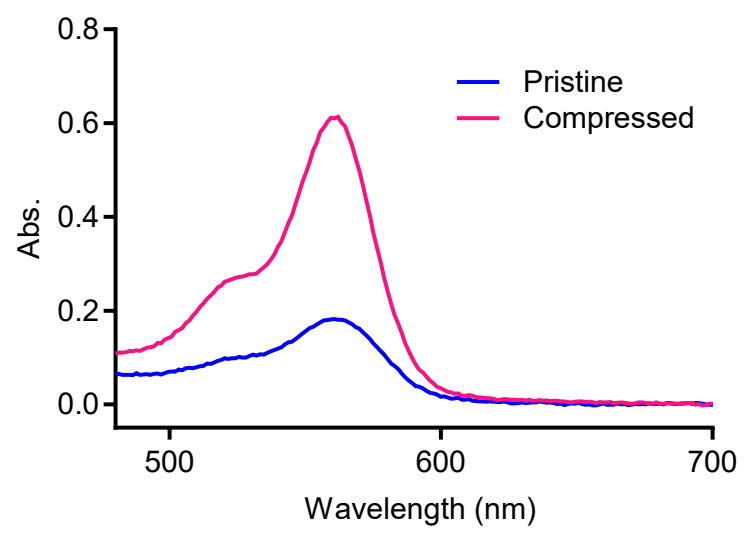

Figure S11. UV-vis spectra of active PDMS cylinder before and after compression. The corresponding absorption at $560 \mathrm{~nm}$ is 0.182 and 0.610 .

The amount of activated MeO-gDCC can be estimated using Beer-Lambert law:

$$
A=\varepsilon l c
$$

Where $\varepsilon=106000 \mathrm{~L} /\left(\mathrm{mol}^{*} \mathrm{~cm}\right)$ is the extinction coefficient of rhodamine $\mathrm{B}, l$ is the length (the thickness of PDMS cylinder in our case) and $c$ is the concentration in the matrix.

Assuming each released $\mathrm{HCl}$ protonated one rhodamine dye, we can calculate the concentration of released $\mathrm{HCl}$ :

$$
c=\frac{A}{\varepsilon l}=\frac{0.610-0.182}{106000 * 0.3}=1.342 \times 10^{-5} \mathrm{~mol} / \mathrm{L}
$$

We incorporated $11 \mathrm{mg} \mathrm{MeO-gDCC}$ into $2.2 \mathrm{~g}$ PDMS material $(\rho=0.965)$. If we assumed the volume of PDMS does not change after curing, the total concentration of $\mathrm{MeO}-\mathrm{gDCC}$ in the matrix could be obtained:

$$
c_{0}=\frac{m}{M V}=\frac{11 \times 10^{-3}}{395 *\left(2.2 / 0.965 \times 10^{-3}\right)}=1.266 \times 10^{-3} \mathrm{~mol} / \mathrm{L}
$$

Since $\sim 0.58$ equivalents of $\mathrm{HCl}$ is generated per $\mathrm{MeO}-\mathrm{gDCC}$, the activation percentage is: $\mathrm{c} / 0.58 / \mathrm{c}_{0} * 100 \%=0.18 \%$ 


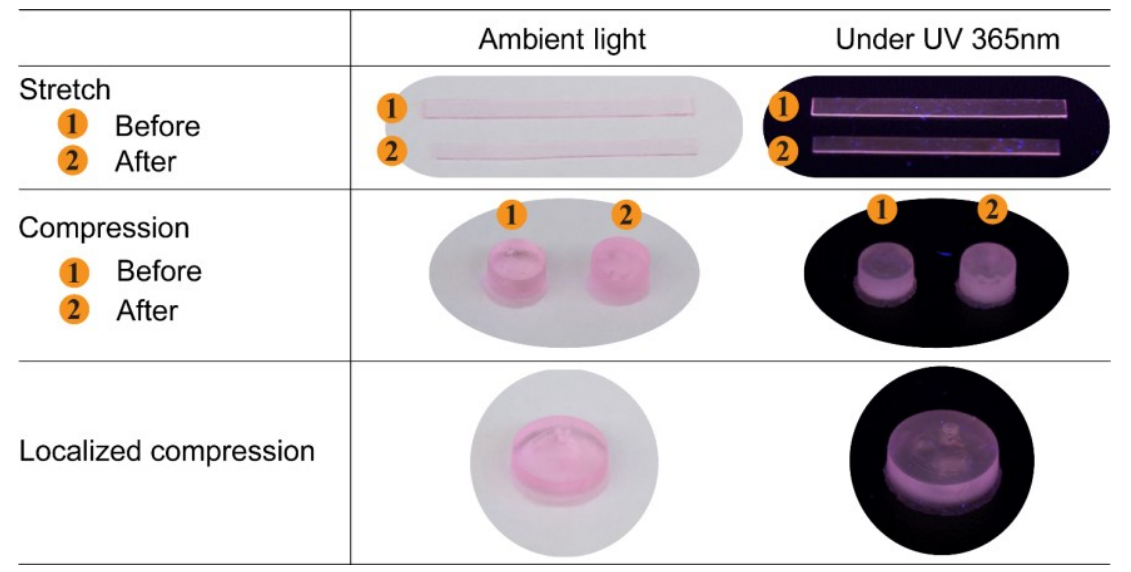

Figure S12. Results of control 1 sample (rhodamine 9) under different models of mechanical load.

\begin{tabular}{l|ll}
\hline & & Ambient light
\end{tabular}

Figure S13. Results of control 2 sample (rhodamine 9 and control 7) under different models of mechanical load.

\section{Time-dependent mechanochromism}

An active PDMS cylinder (diameter: $\sim 6 \mathrm{~mm}$, thickness: $\sim 3 \mathrm{~mm}$ ) was struck with a hammer, and the evolution in UVvis absorbance at $560 \mathrm{~nm}\left(\mathrm{~A}_{560}\right)$ was recorded as a function of time over $8 \mathrm{~h}$. Several runs were performed, and recorded results were shown in the following:
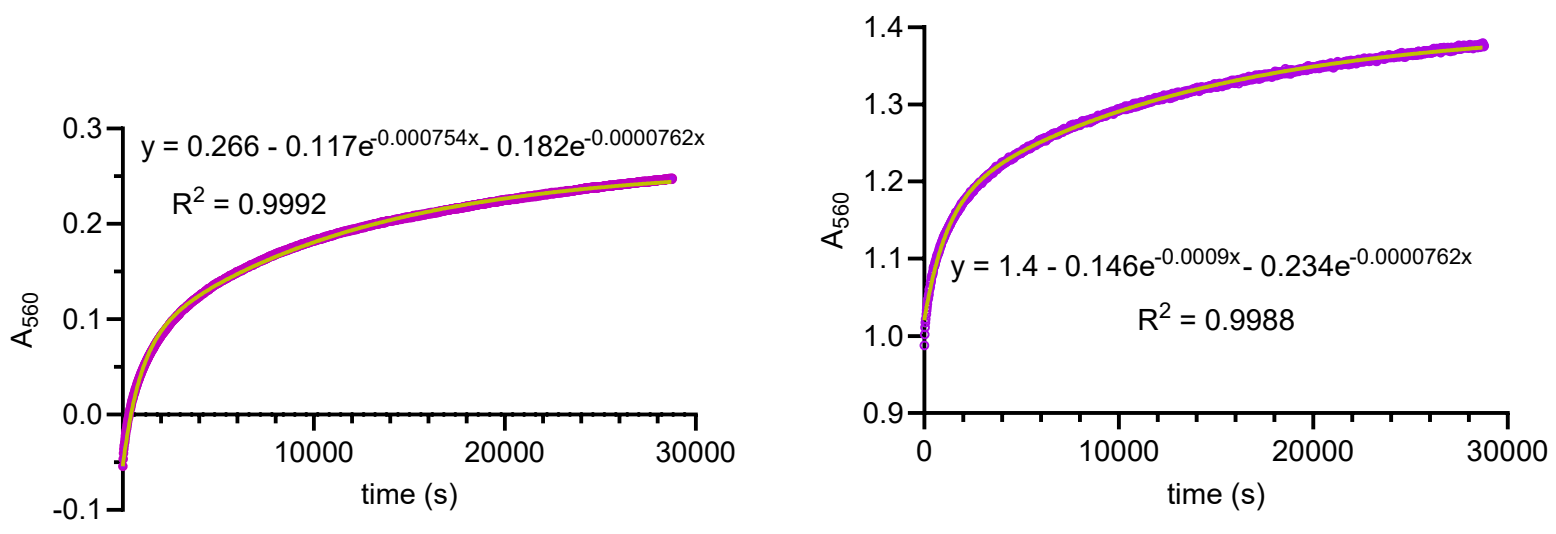

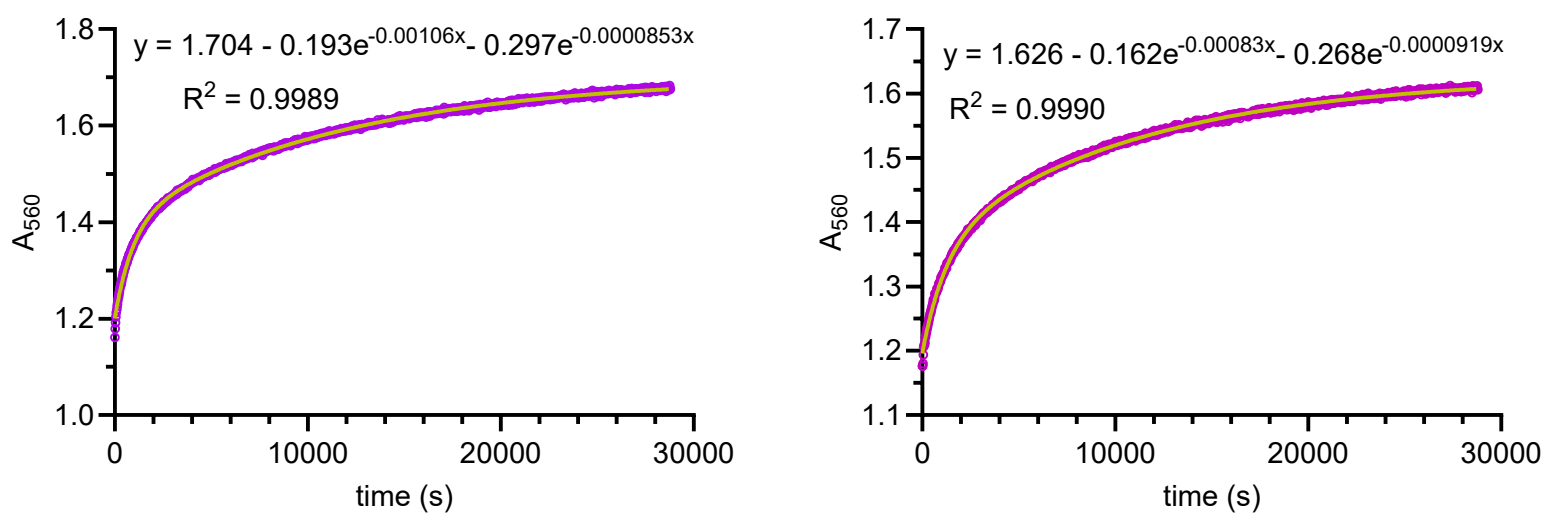

Figure S14. Four different runs of $\mathrm{A}_{560}$ evolution in active PDMS cylinder after hammer strike. The data were fitted with a two-phase association (yellow line, fitting results are shown in the figure).

These curves are further fitted with the following two-phase association equation (1):

$$
\begin{aligned}
& A=A_{\infty}-A_{f} e^{-k_{f} t}-A_{s} e^{-k_{S} t} \\
& A_{f}=\left(A_{\infty}-A_{0}\right) * f \% \\
& A_{s}=\left(A_{\infty}-A_{0}\right) *(1-f \%)
\end{aligned}
$$

$A$ is absorption as measured; $A_{0}$ and $A_{\infty}$ are initial and final absorption; while $k_{f}$ and $k_{s}$ stand for rate constant of fast and slow phases, respectively; $f \%$ refers to contribution of fast phase.

These four runs are normalized using the following equation:

$$
I=A /\left(A_{\infty}-A_{0}\right)
$$

Where $A$ is the recorded absorption, $A_{\infty}$ and $A_{0}$ are final and initial absorption.

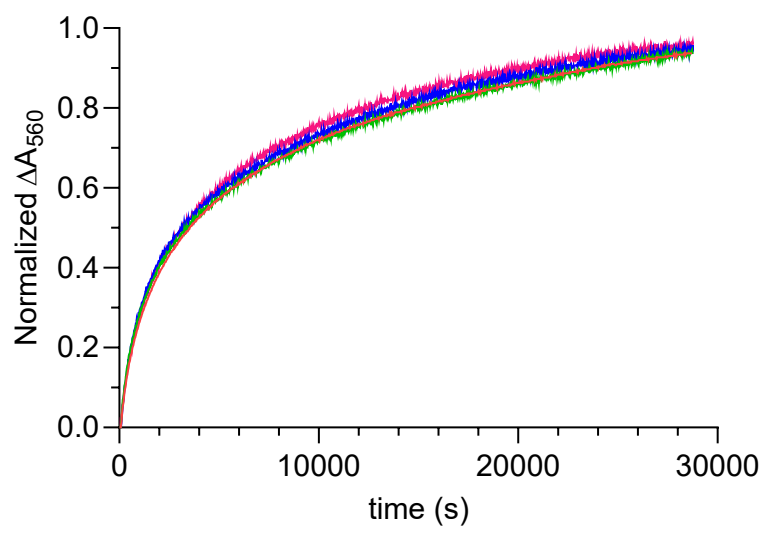

Figure S15. Overlay of normalized turn-on kinetics. These data are treated as standard curves and provide: $k_{f}=$ $(8.86 \pm 1.30) \times 10^{-4} \mathrm{~s}^{-1}, k_{s}=(8.24 \pm 0.76) \times 10^{-5} \mathrm{~s}^{-1}$, and $f \%=(38.7 \pm 0.7) \%$.

For a sample with an unknown mechanical load time point, we anticipated that recorded kinetics would allow to extrapolate back the time point. To test this concept, we recorded the initial absorption $\left(A_{0}\right)$ of samples and subjected the sample to hammer strike. The kinetics data at $A_{560}$ was recorded for different samples and various times $(6,12,26$ 
min) after hammer strike. These kinetics results were then fitted with the empirical two-phase association (5) using parameters constraints obtained from standard curves in Figure S15.

$$
A=A_{\infty}-A_{f} e^{-k_{f}\left(t-t_{\text {wait }}\right)}-A_{s} e^{-k_{S}\left(t-t_{\text {wait }}\right)}
$$
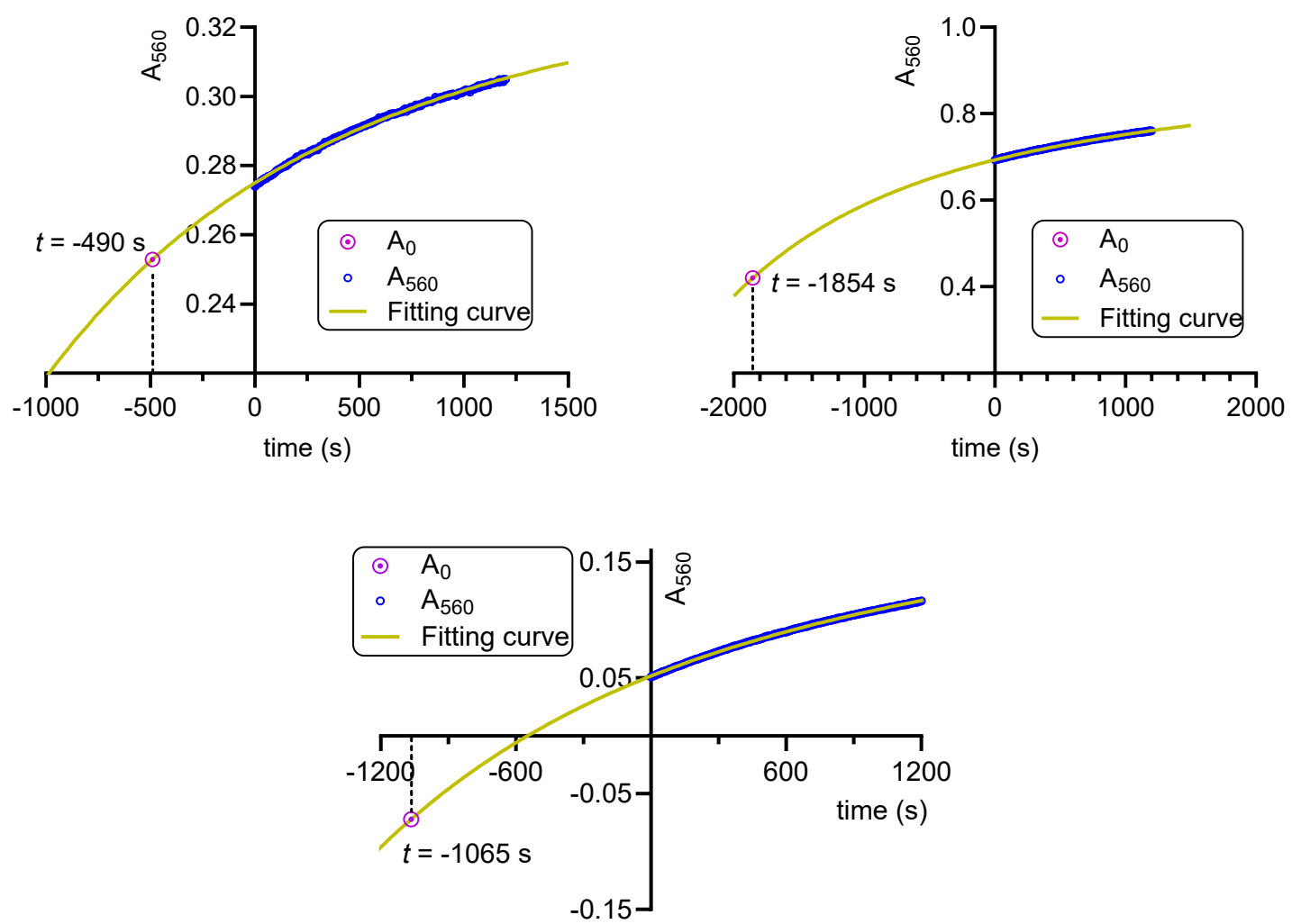

Figure S16. The time point of mechanical load was extrapolated by fitting of kinetics data. The actual time for each sample is 6,26, 12 min, respectively. 


\section{CoGEF modeling}

CoGEF modeling of $\mathrm{MeO}-\mathrm{gDCC}$ and corresponding three species generated after mechanical activation were performed on Spartan'16 V2.0.7 version at Molecular Mechanics/MMFF theory level. The end-to-end distance was constrained and relaxed using the same procedure in reported literature. ${ }^{2,5,7-8}$ The energy at each relaxed step was plotted as a function of distance. Following fitting with a quadratic equation and further analysis from the first derivative gave force vs. extension as a linear relation. Extrapolation of linear curve at zero force provided the contour length $\left(x_{0}\right)$.

MeO-gDCC<smiles>CCCC1(OC)C(Cl)(Cl)C1(CC)OCC</smiles>

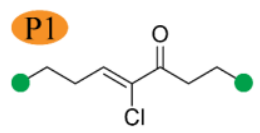

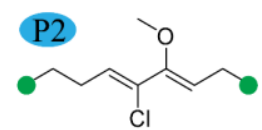

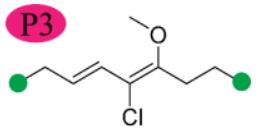

\section{CoGEF modeling of MeO-gDCC}
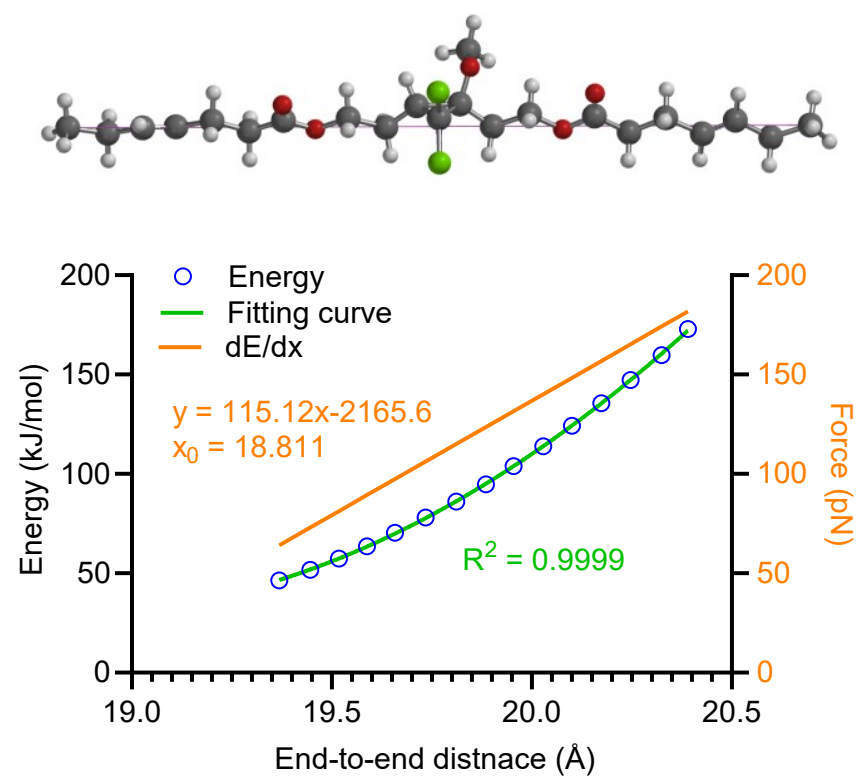

Figure S17. Quadratic fit of energy vs. distance curve (green); force vs. distance plot (orange). End-to-end distance of MeO-gDCC: $18.811 \AA$

\section{CoGEF modeling of P1}

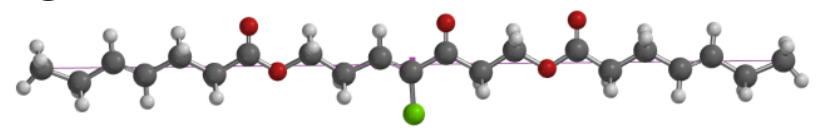




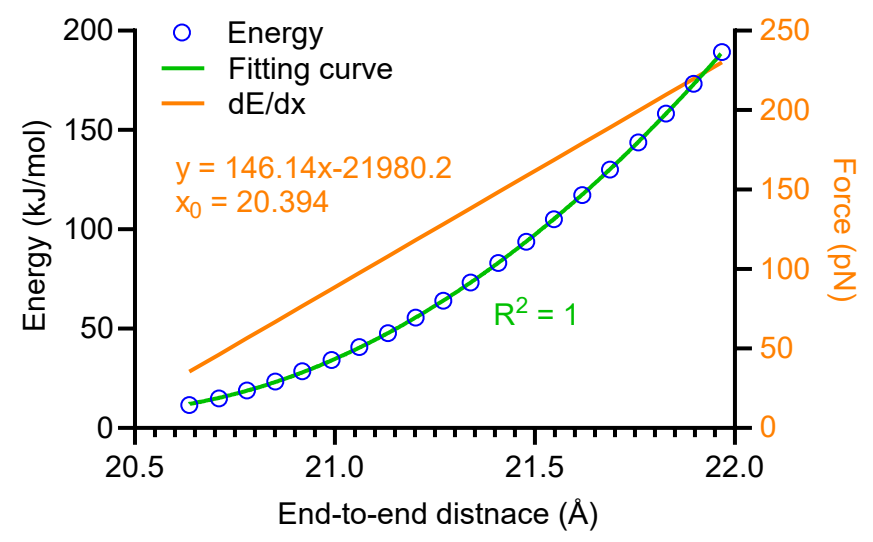

Figure S18. Quadratic fit of energy vs. distance curve (green); force vs. distance plot (orange). End-to-end distance of P1: $20.394 \AA$

\section{CoGEF modeling of P2}
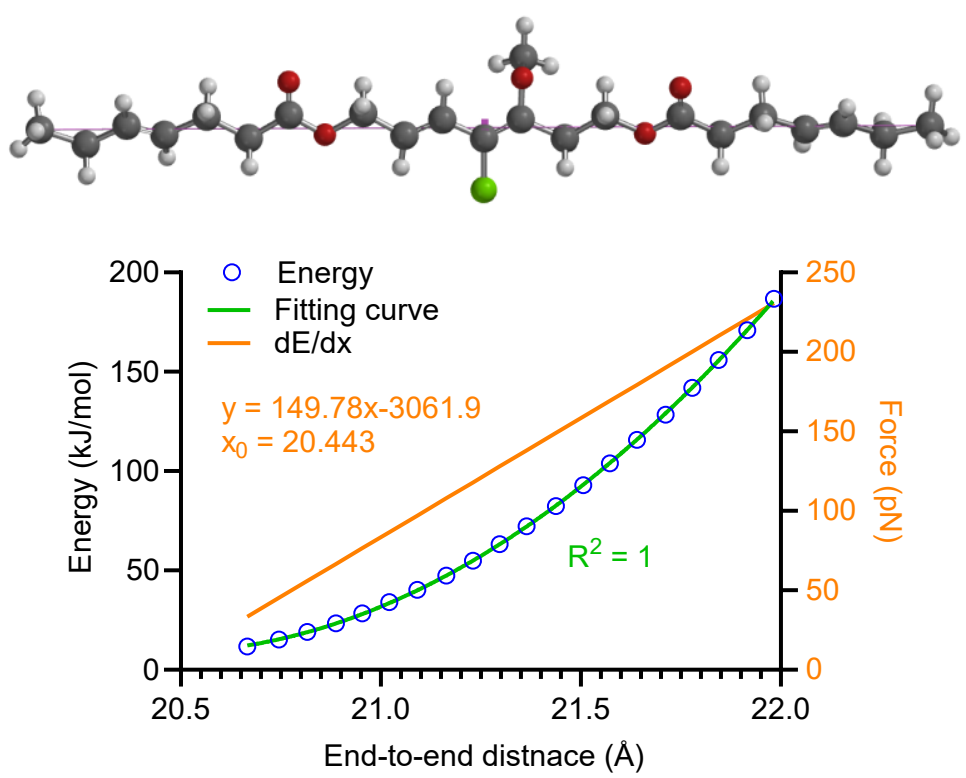

Figure S19. Quadratic fit of energy vs. distance curve (green); force vs. distance plot (orange). End-to-end distance of P2: $20.443 \AA$

\section{CoGEF modeling of P3}

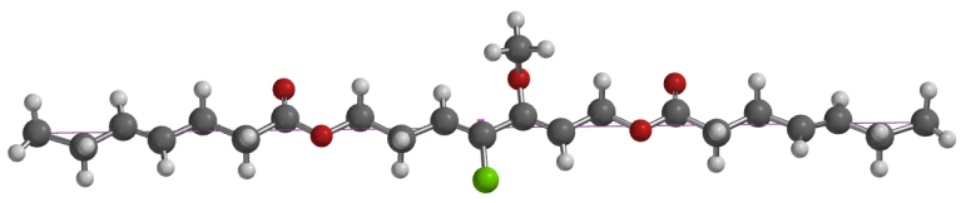




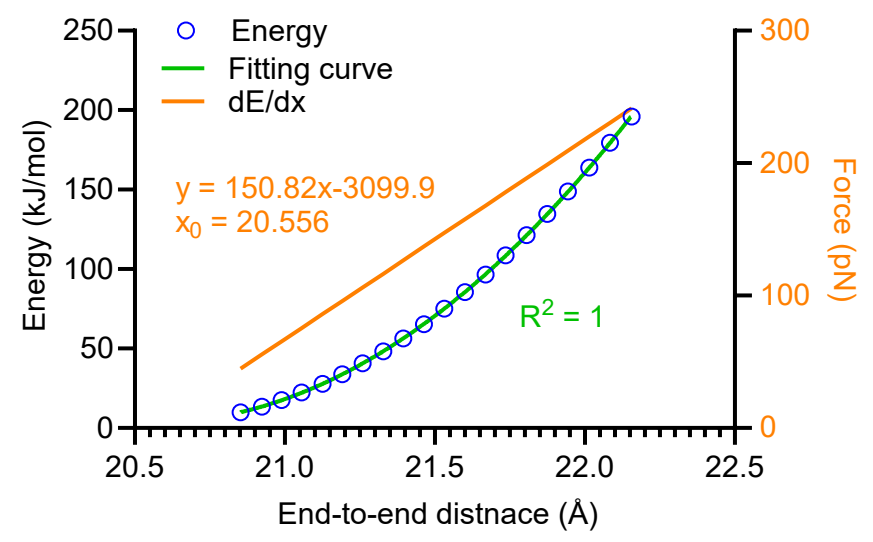

Figure S20. Quadratic fit of energy vs. distance curve (green); force vs. distance plot (orange). End-to-end distance of P3: $20.556 \AA$

Table S2. Summary of modeling contour length (unit: $\AA$ )

\begin{tabular}{ccccc}
\hline & MeO-gDCC & P1 & P2 & P3 \\
\hline Trial 1 & 18.810 & 20.397 & 20.446 & 25.556 \\
Trial 2 & 18.811 & 20.393 & 20.443 & 25.553 \\
Trial 3 & 18.836 & 20.394 & 20.441 & 25.556 \\
\hline Avg. & 18.819 & 20.394 & 20.443 & 25.555 \\
SD. & 0.015 & 0.002 & 0.003 & 0.002 \\
\hline$\Delta$ L & $/$ & 1.575 & 1.624 & 1.736 \\
\hline
\end{tabular}

\section{Modeling contour length of epoxide repeating unit}

1) Epoxide repeating unit with cis-olefin
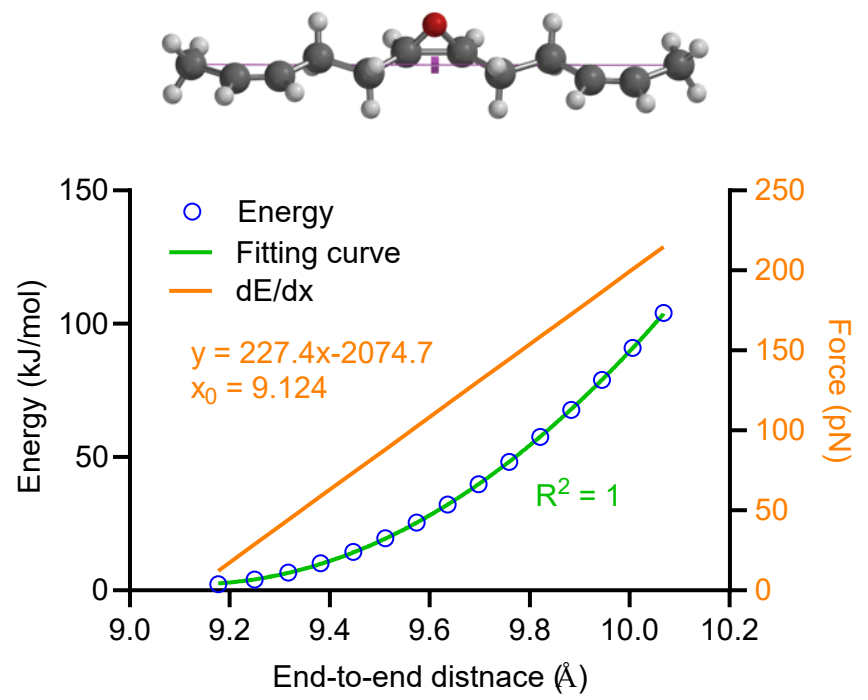

Figure S21. Quadratic fit of energy vs. distance curve (green); force vs. distance plot (orange). End-to-end distance of epoxide repeating unit with cis-olefin: $9.124 \AA$ 
2) Epoxide repeating unit with trans-olefin
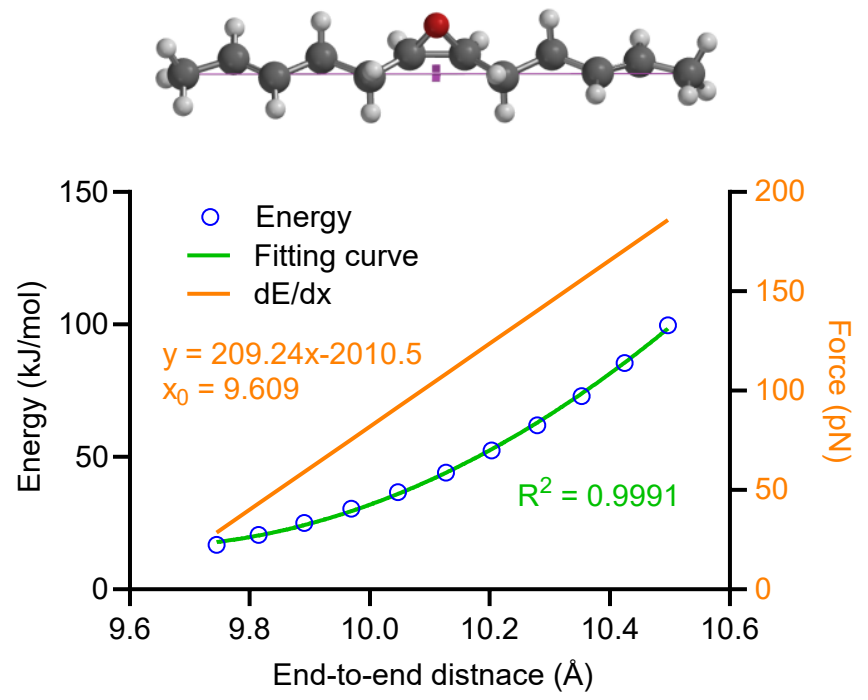

Figure S22. Quadratic fit of energy vs. distance curve (green); force vs. distance plot (orange). End-to-end distance of epoxide repeating unit with trans-olefin: $9.609 \AA$

Table S3. Summary of modeling contour length for epoxide repeating unit (unit: $\AA$ )

\begin{tabular}{cccc}
\hline & Cis & Trans & Average \\
\hline Trial 1 & 9.124 & 9.583 & \\
Trial 2 & 9.126 & 9.609 & $/$ \\
Trial 3 & 9.126 & 9.628 & \\
\hline Avg. & 9.125 & 9.607 & 9.366 \\
SD. & 0.004 & 0.001 & $/$ \\
\hline
\end{tabular}

The ratio of final contour length $\left(\mathrm{L}_{\mathrm{f}}\right)$ to initial contour length $\left(\mathrm{L}_{\mathrm{i}}\right)$ was was calculated according to the following equation:

$$
\frac{L_{f}}{L_{i}}=\frac{x * l_{f}+(1-x) * l_{C O D}}{x * l_{i}+(1-x) * l_{C O D}}
$$

$L_{i}, l_{i}$ represent for initial contour lengths of polymer and mechanophore repeating unit; $L_{f}, l_{f}$, refer to final contour lengths of polymer and mechanophore repeating unit; $l_{C O D}$ stands for contour length of epoxide repeating unit; $x$ denotes the molar fraction of mechanophore in the polymer. $l_{i}, l_{f}$ and $l_{C O D}$ were determined from CoGEF modeling and $x$ was calculated from ${ }^{1} \mathrm{H}$ NMR spectrum.

For $47 \mathrm{~mol} \% \mathrm{MeO}-\mathrm{gDCC}$ containing ROMP copolymer, the ratio of product P1: P2: P3 is 27:31:7, we have:

$$
\frac{L_{f}}{L_{i}}=\frac{0.47 *(27 * 20.394+31 * 20.443+7 * 20.555) / 65+0.53 * 9.366}{0.47 * 18.819+0.53 * 9.366}=1.063
$$

This number agrees well with results observed form SMFS experiment. 


\section{NMR spectra}

$\stackrel{\substack{0 \\ \text { i }}}{1}$

Compound 1

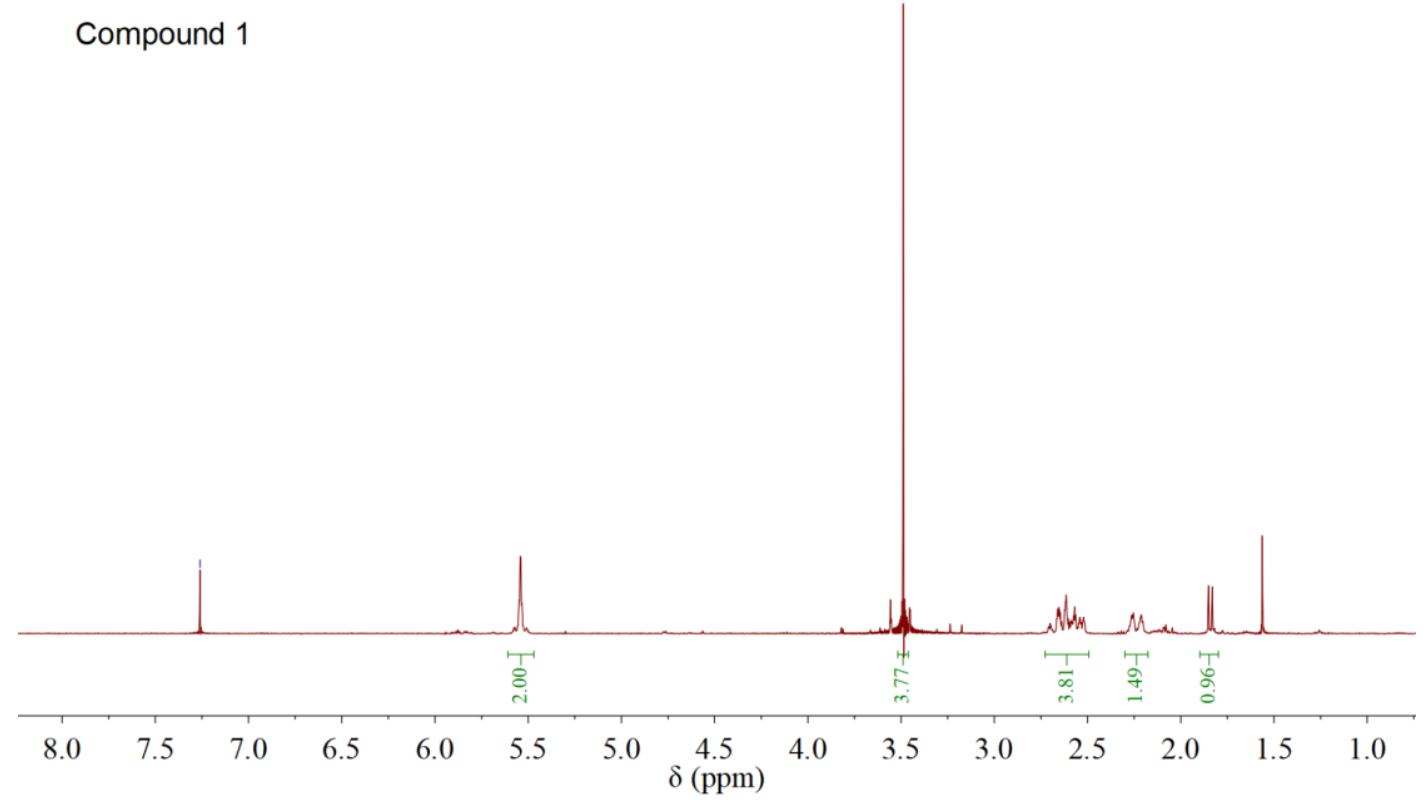

${ }^{1} \mathrm{H} \mathrm{NMR}\left(400 \mathrm{MHz}, \mathrm{CDCl}_{3}\right)$ spectrum of compound $\mathbf{1}$

\begin{tabular}{|c|c|c|}
\hline 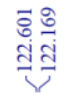 & 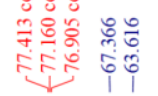 & 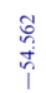 \\
\hline
\end{tabular}

Compound 1

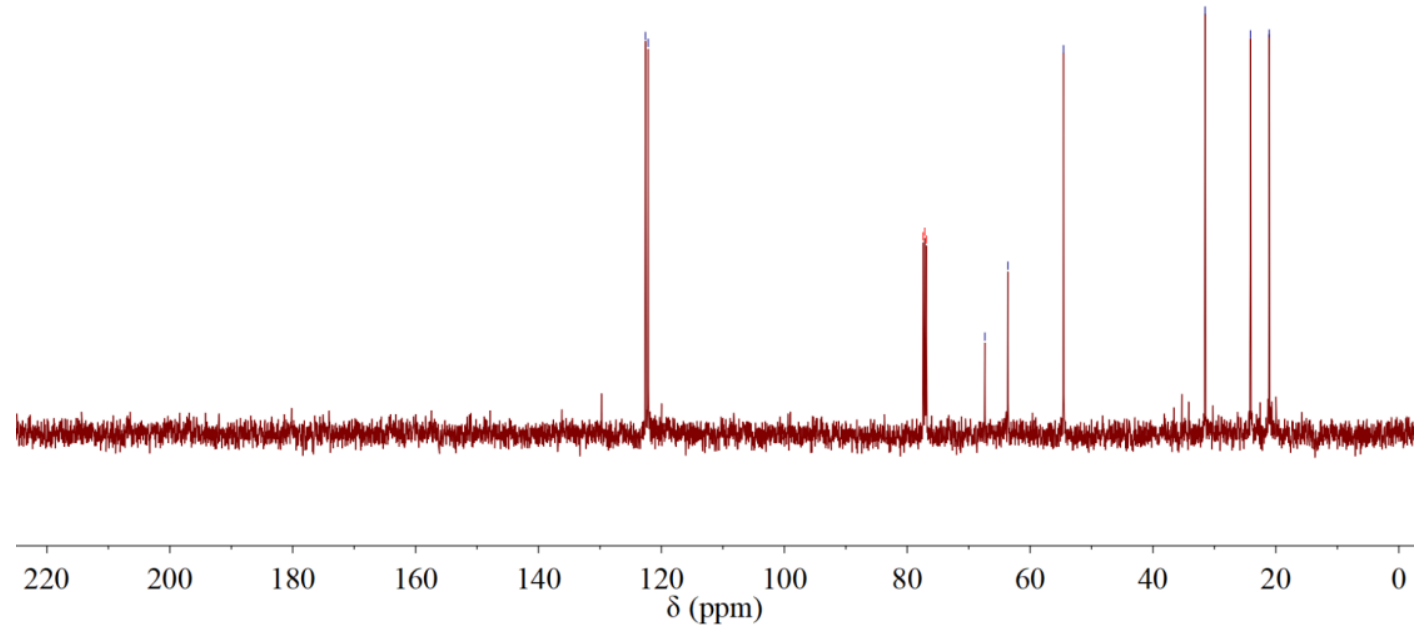

${ }^{13} \mathrm{C}$ NMR $\left(125 \mathrm{MHz}, \mathrm{CDCl}_{3}\right)$ spectrum of compound $\mathbf{1}$ 


\section{Compound 2}

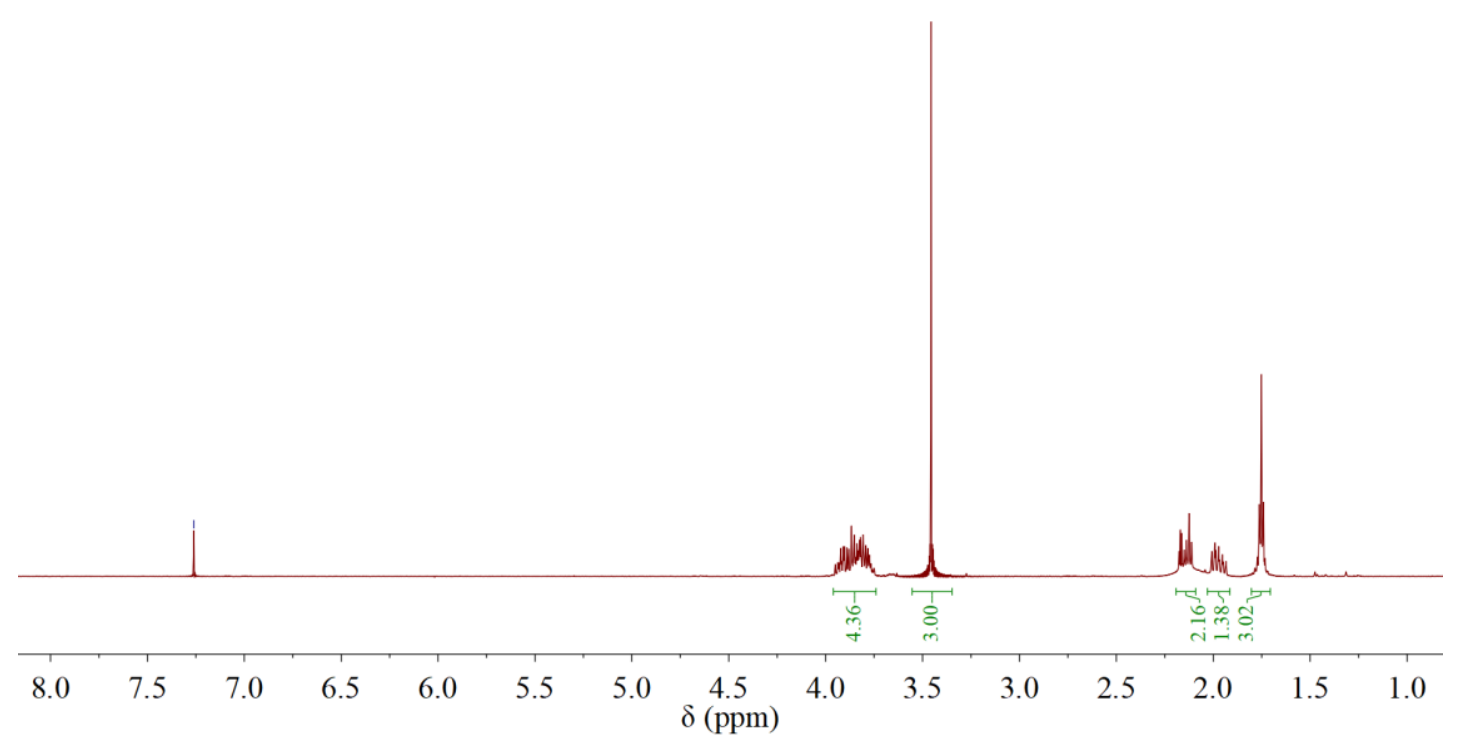

${ }^{1} \mathrm{H}$ NMR (400 MHz, $\mathrm{CDCl}_{3}$ ) spectrum of compound 2

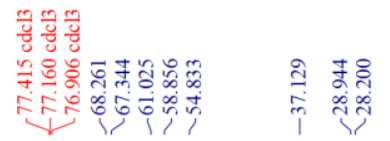

Compound 2

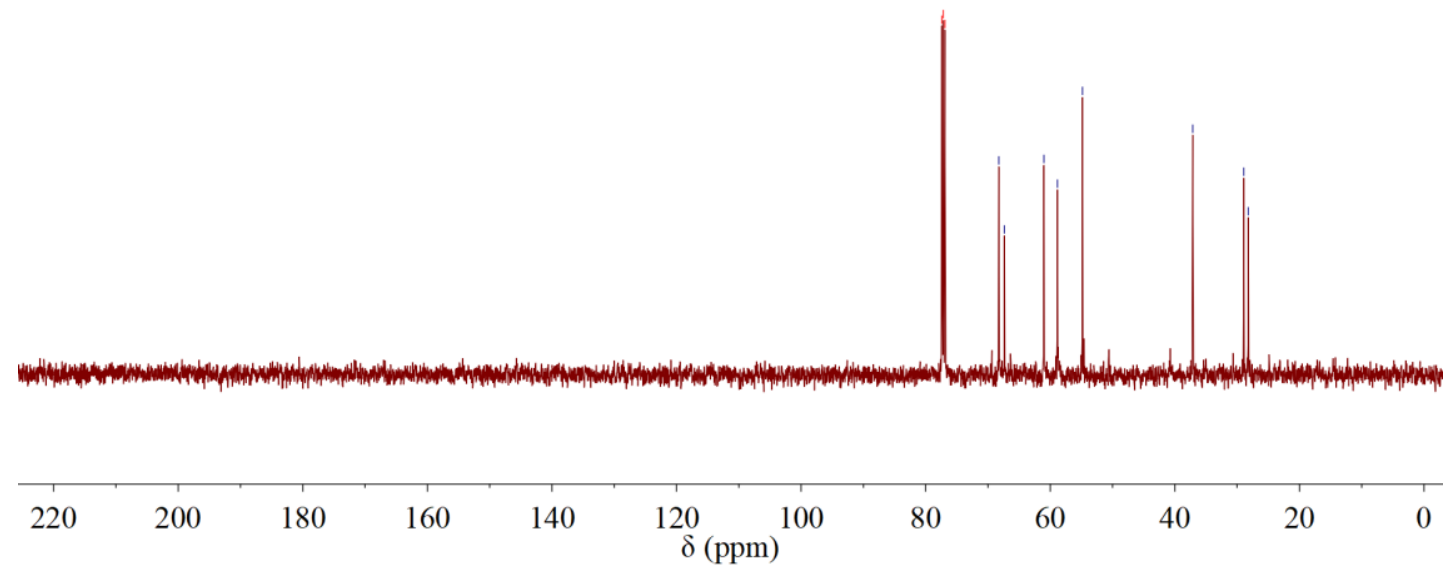

${ }^{13} \mathrm{C}$ NMR $\left(125 \mathrm{MHz}, \mathrm{CDCl}_{3}\right)$ spectrum of compound 2 


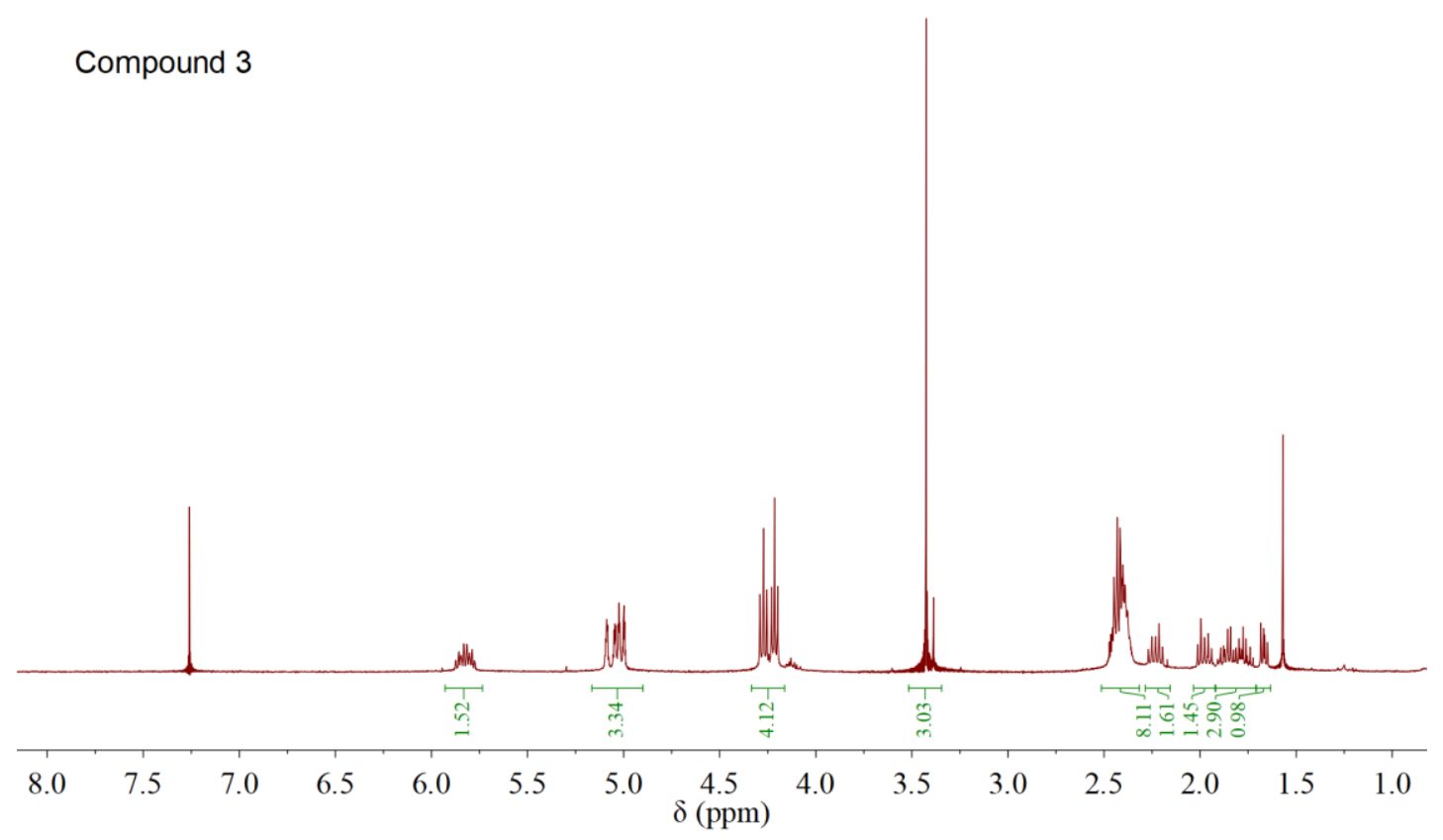

${ }^{1} \mathrm{H}$ NMR (400 MHz, $\mathrm{CDCl}_{3}$ ) spectrum of compound 3

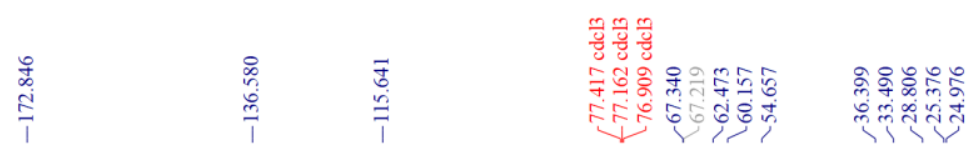

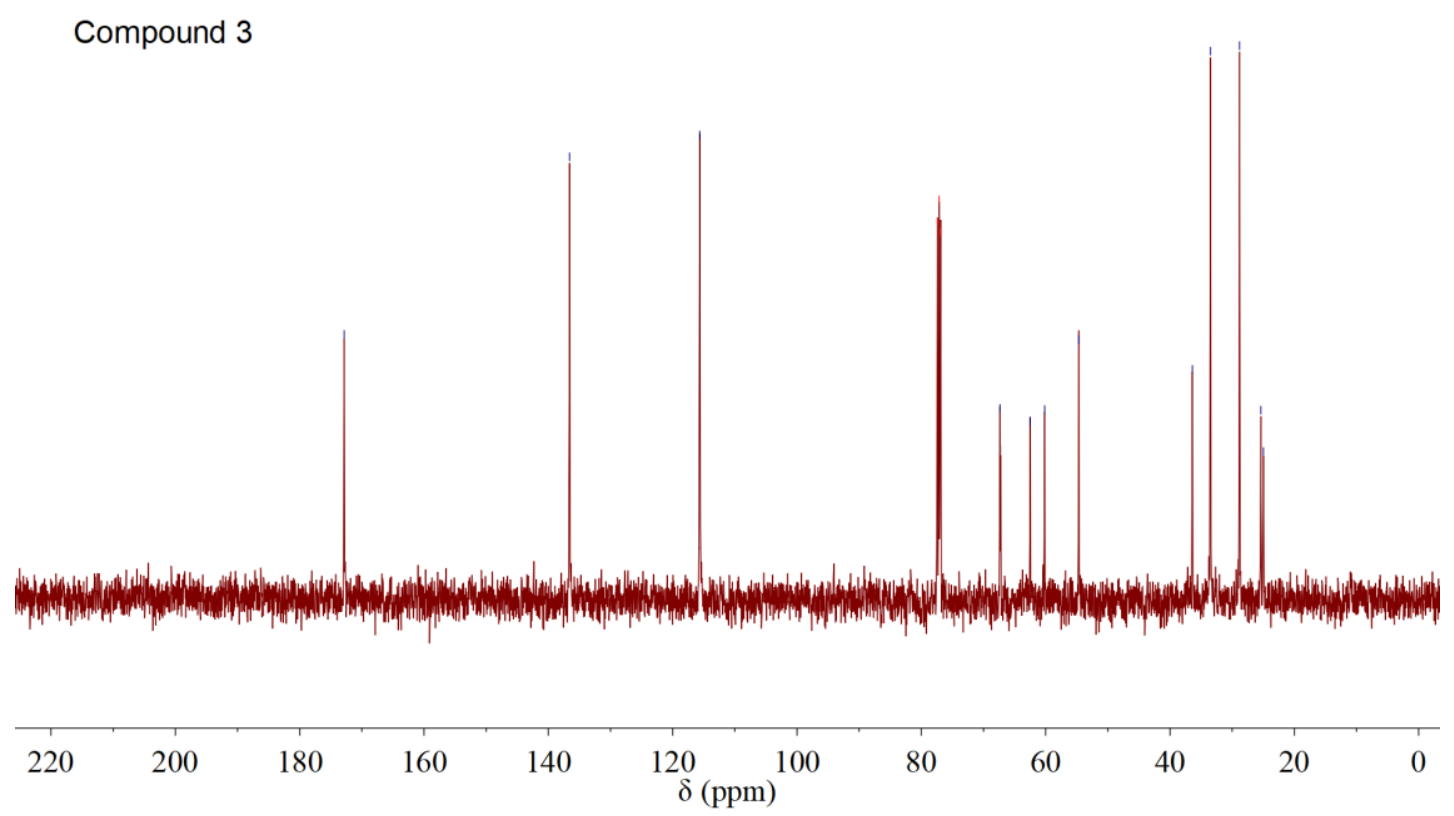

${ }^{13} \mathrm{C}$ NMR (125 MHz, $\left.\mathrm{CDCl}_{3}\right)$ spectrum of compound $\mathbf{3}$ 


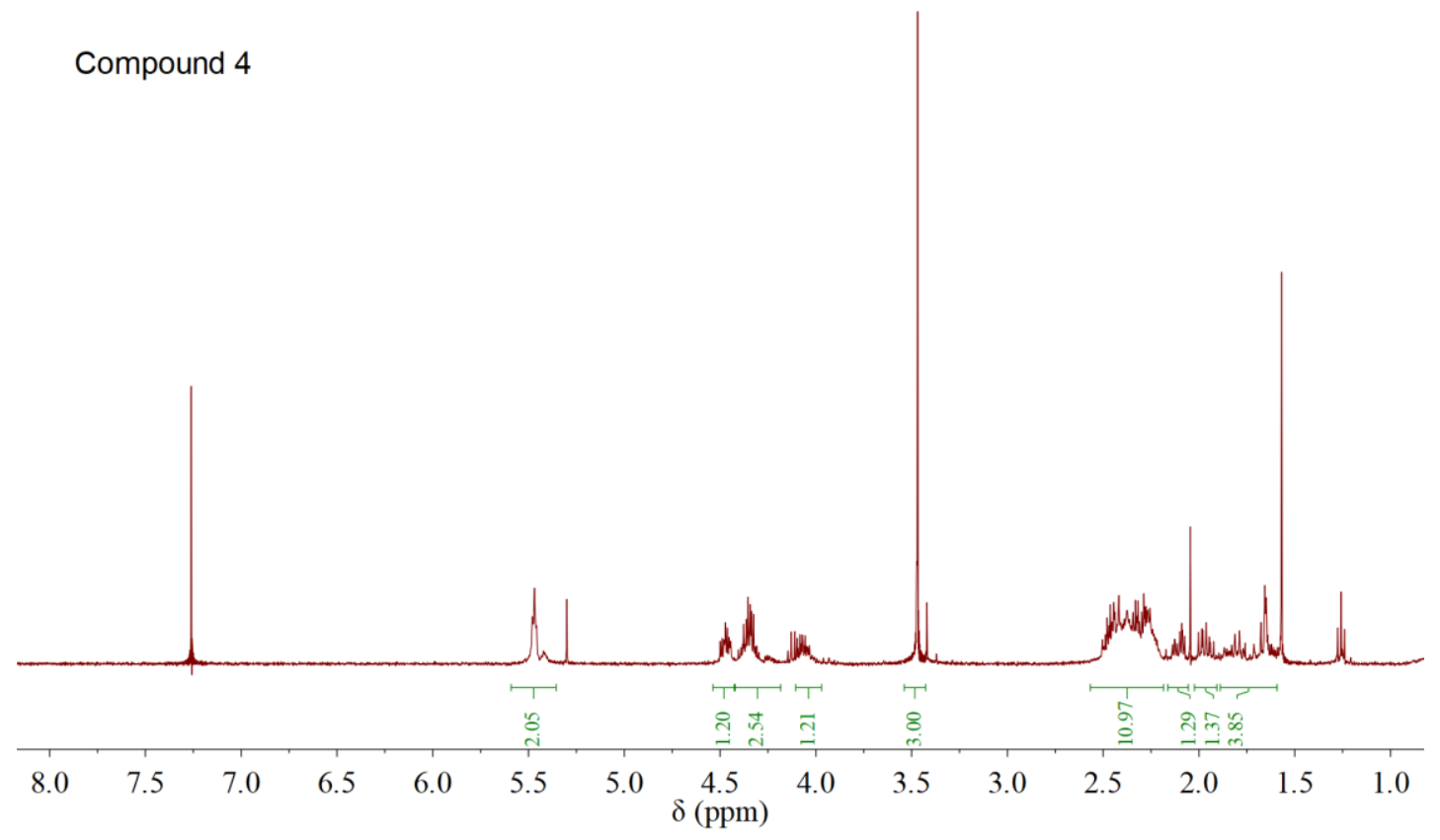

${ }^{1} \mathrm{H}$ NMR (400 MHz, $\mathrm{CDCl}_{3}$ ) spectrum of compound 4

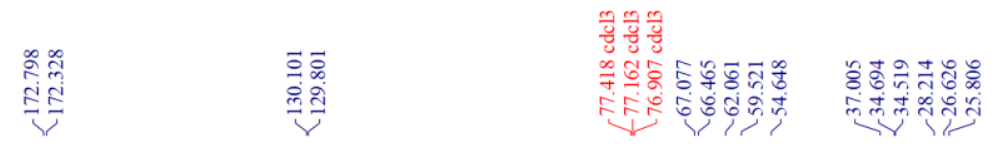

Compound 4

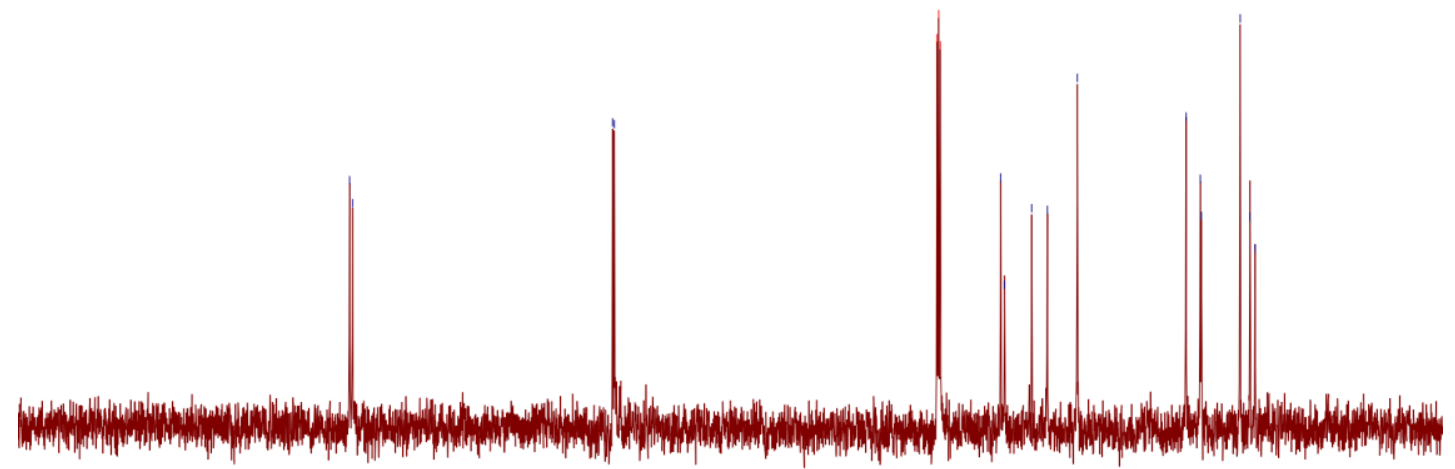

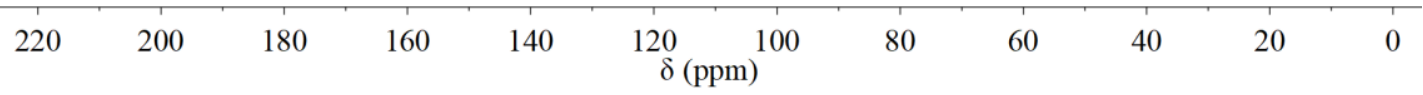

${ }^{13} \mathrm{C}$ NMR $\left(125 \mathrm{MHz}, \mathrm{CDCl}_{3}\right)$ spectrum of compound 4 


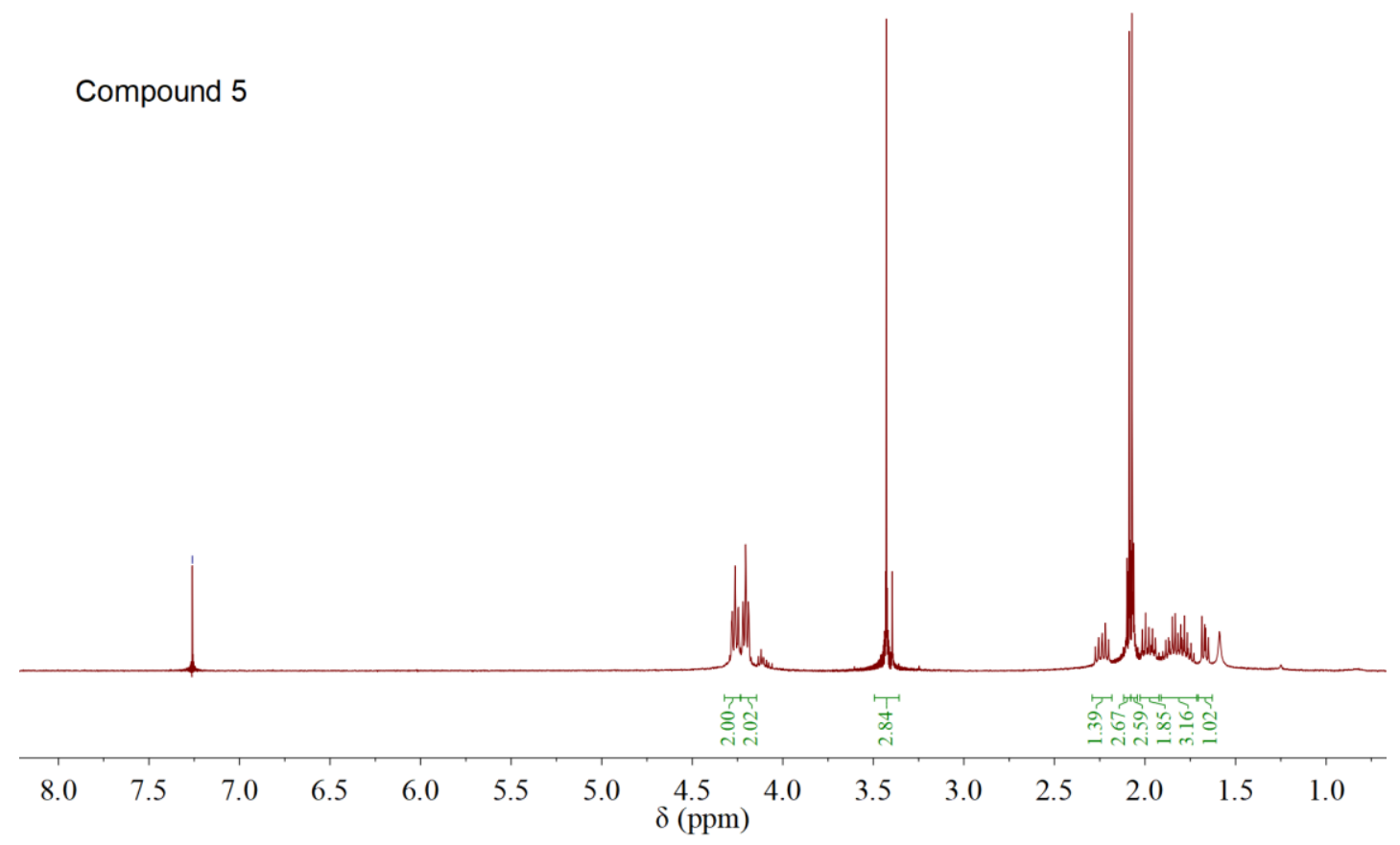

${ }^{1} \mathrm{H}$ NMR (400 MHz, $\mathrm{CDCl}_{3}$ ) spectrum of compound 5

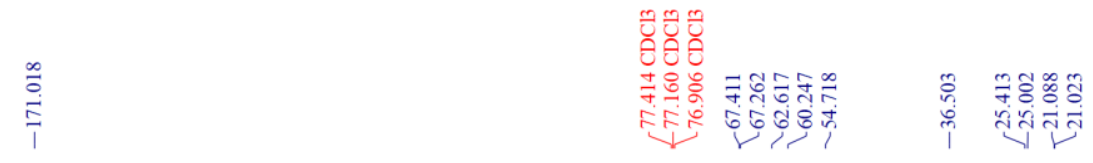

Compound 5

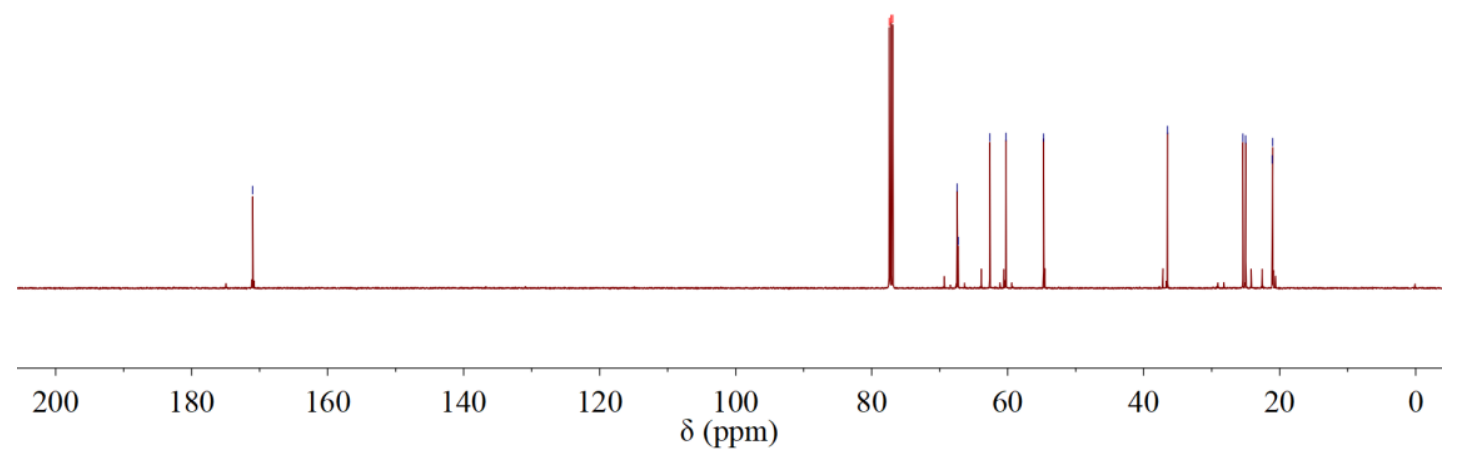

${ }^{13} \mathrm{C}$ NMR $\left(125 \mathrm{MHz}, \mathrm{CDCl}_{3}\right)$ spectrum of compound $\mathbf{5}$ 


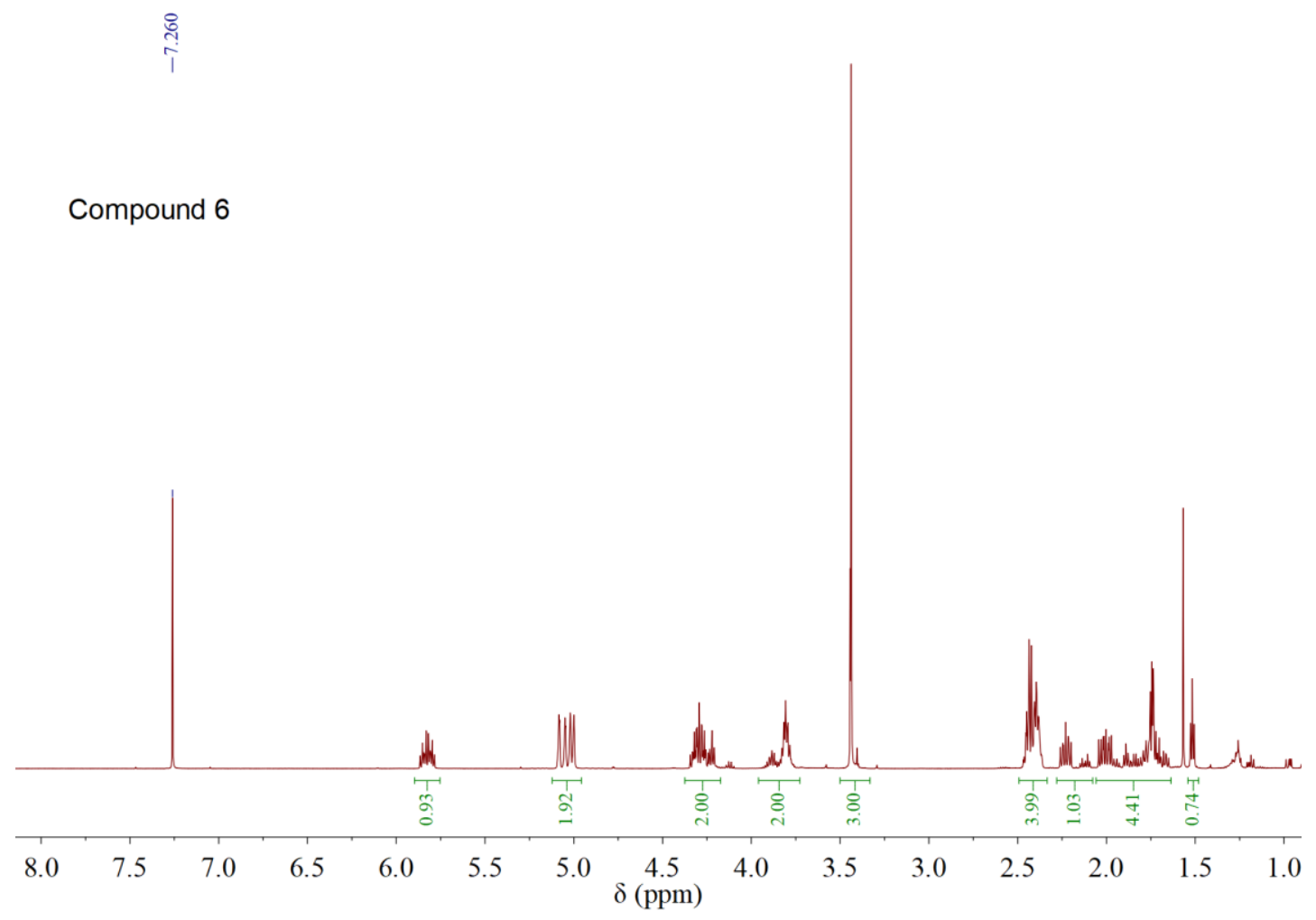

${ }^{1} \mathrm{H}$ NMR (400 MHz, $\mathrm{CDCl}_{3}$ ) spectrum of compound 6

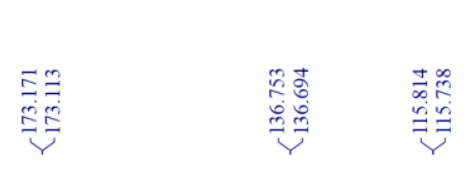

Compound 6

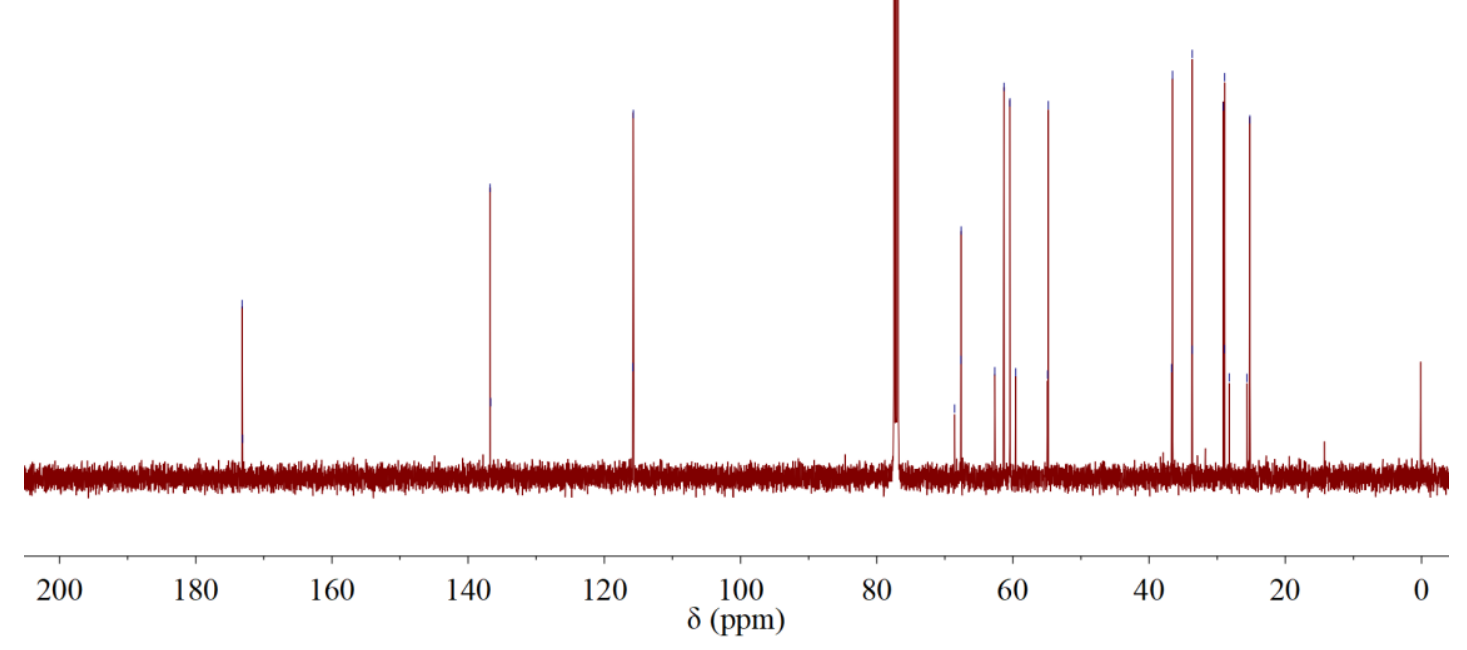

${ }^{13} \mathrm{C}$ NMR $\left(125 \mathrm{MHz}, \mathrm{CDCl}_{3}\right)$ spectrum of compound $\mathbf{6}$ 


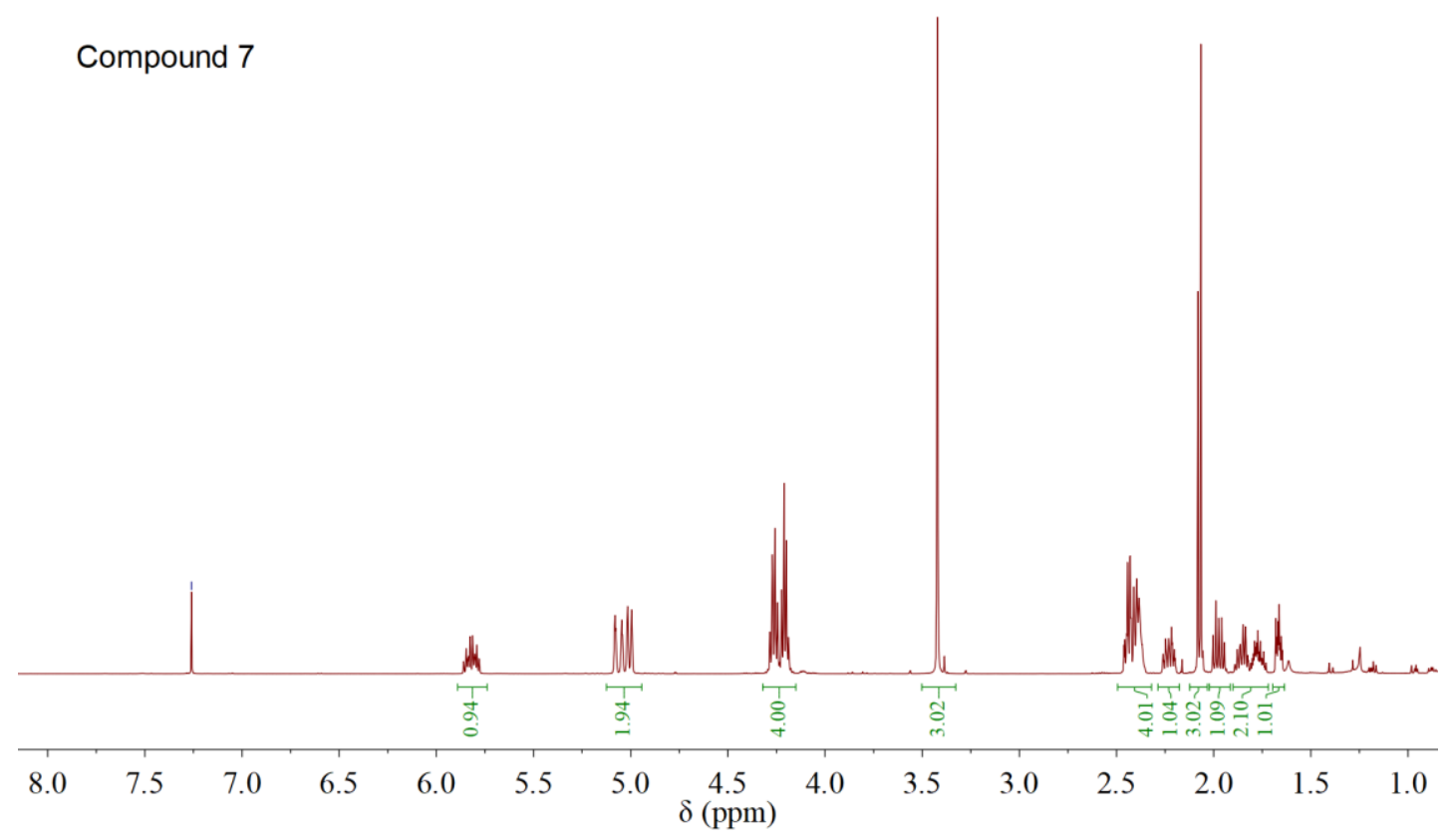

${ }^{1} \mathrm{H}$ NMR (400 MHz, $\mathrm{CDCl}_{3}$ ) spectrum of compound 7

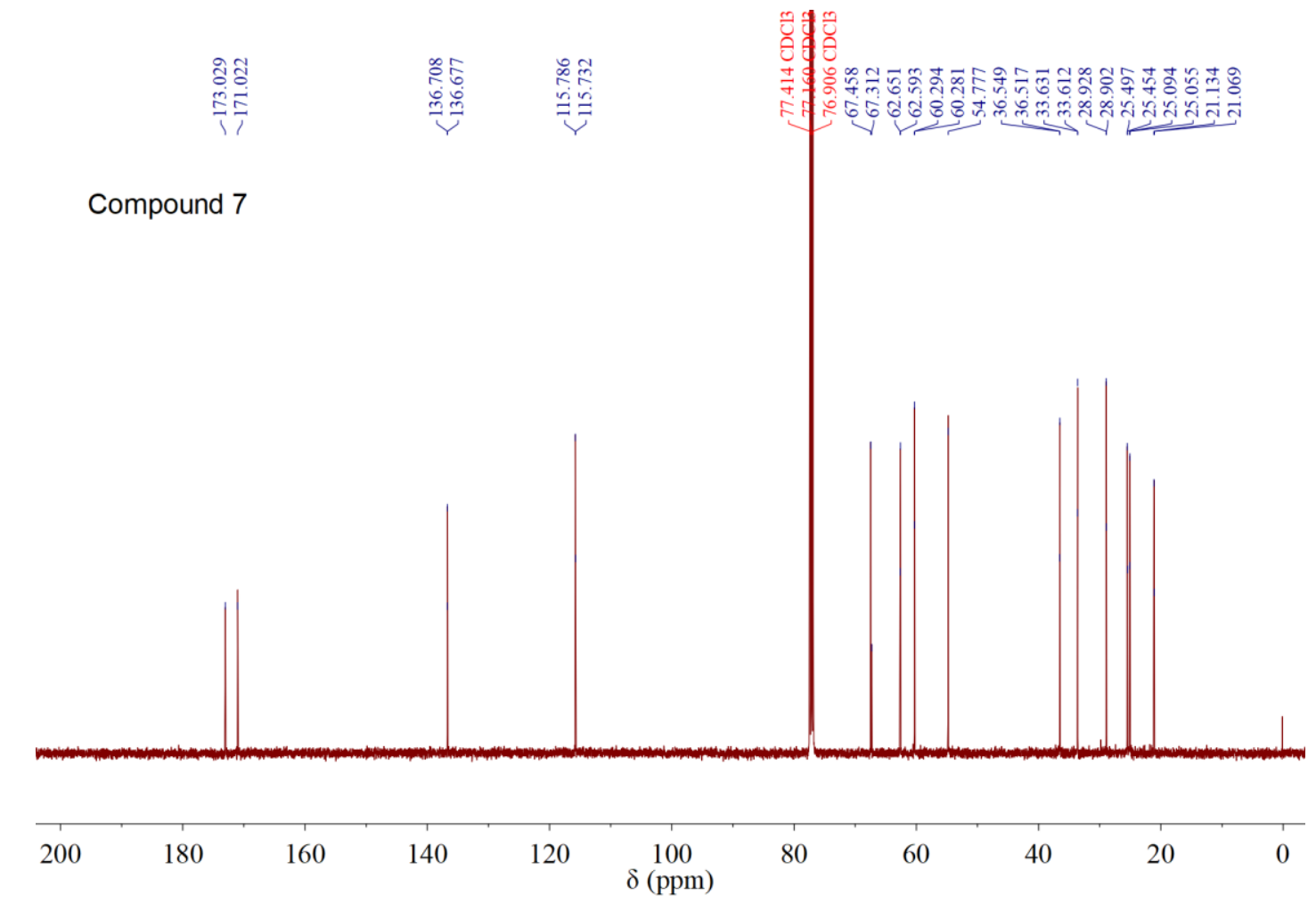

${ }^{13} \mathrm{C}$ NMR (125 MHz, $\mathrm{CDCl}_{3}$ ) spectrum of compound 7 


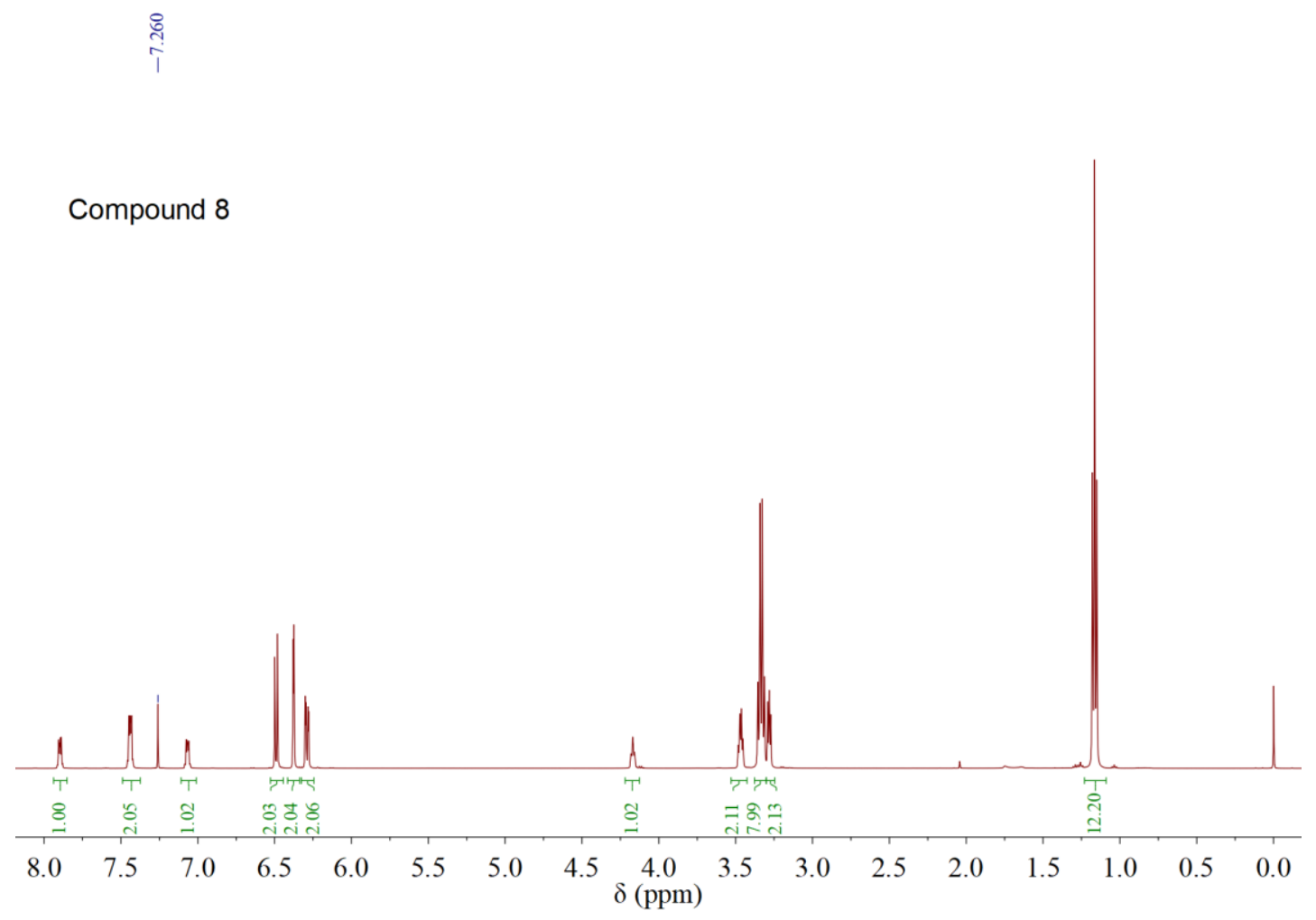

${ }^{1} \mathrm{H}$ NMR (400 MHz, $\mathrm{CDCl}_{3}$ ) spectrum of compound 8
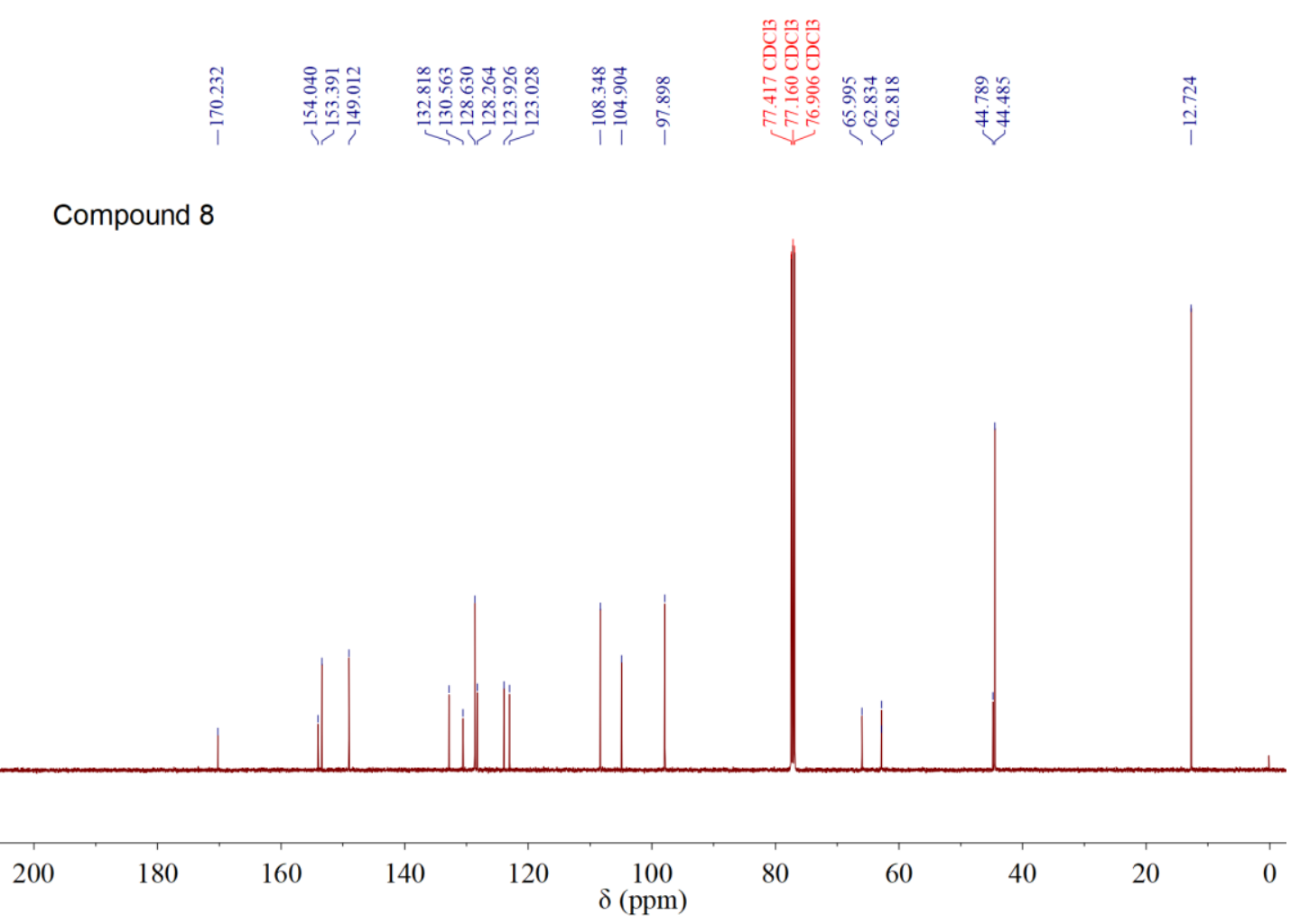

${ }^{13} \mathrm{C}$ NMR (125 MHz, $\left.\mathrm{CDCl}_{3}\right)$ spectrum of compound $\mathbf{8}$ 


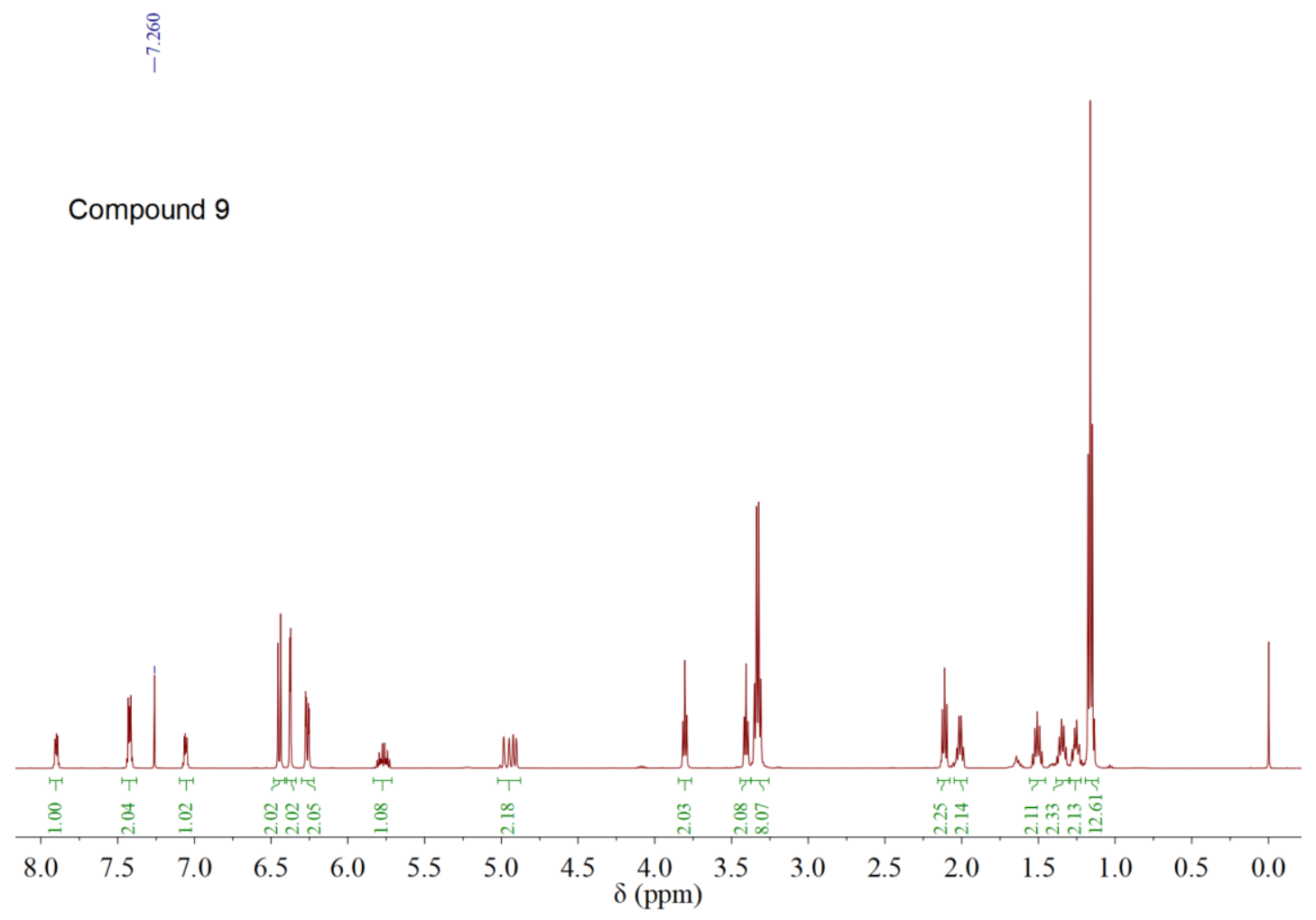

${ }^{1} \mathrm{H}$ NMR (400 MHz, $\mathrm{CDCl}_{3}$ ) spectrum of compound 9

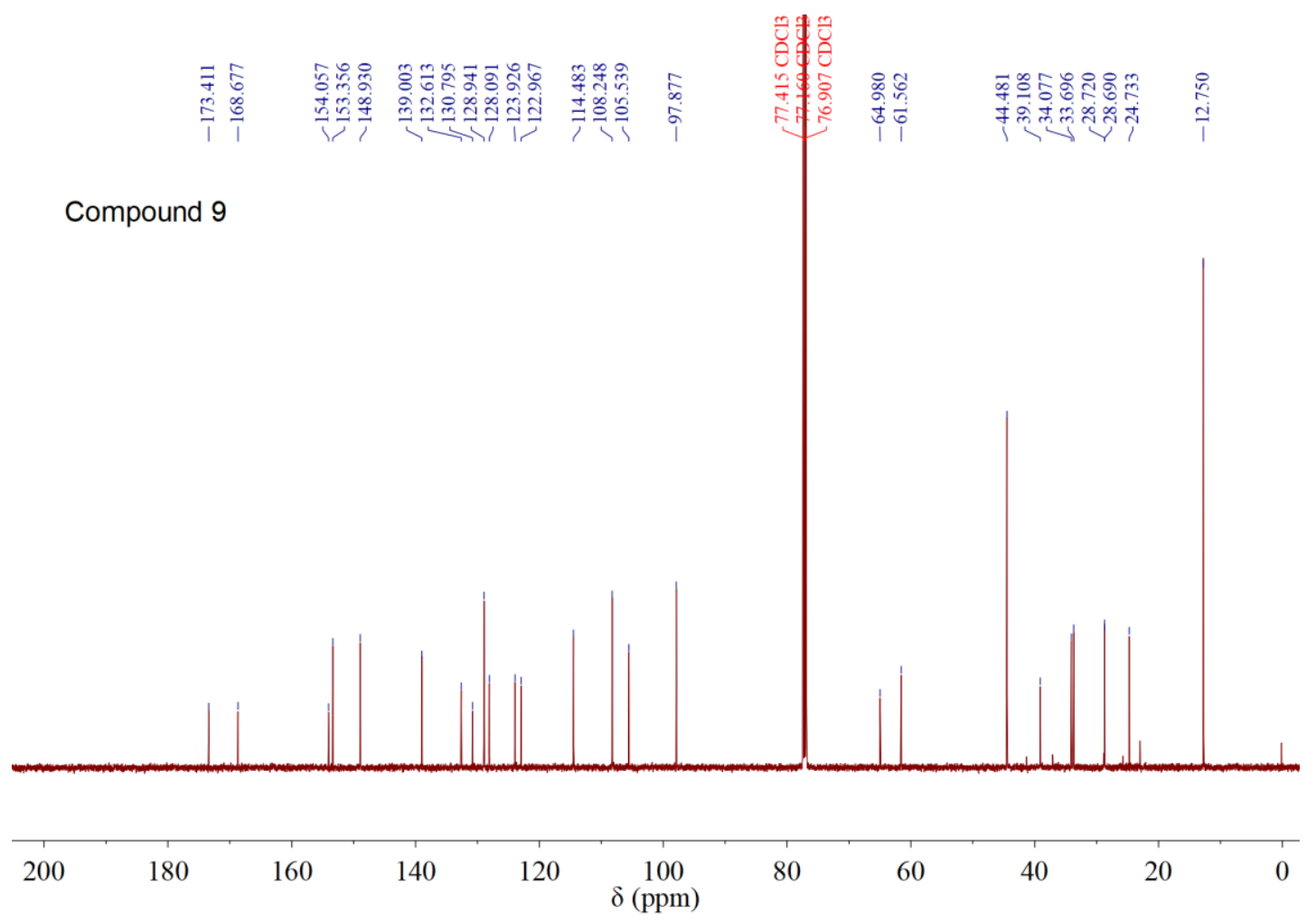

${ }^{13} \mathrm{C}$ NMR $\left(125 \mathrm{MHz}, \mathrm{CDCl}_{3}\right)$ spectrum of compound 9 


\section{Reference}

1. Klukovich, H. M.; Kouznetsova, T. B.; Kean, Z. S.; Lenhardt, J. M.; Craig, S. L. A Backbone Lever-Arm Effect Enhances Polymer Mechanochemistry. Nat. Chem. 2013, 5, 110-114.

2. $\quad$ Wang, J.; Kouznetsova, T. B.; Niu, Z.; Ong, M. T.; Klukovich, H. M.; Rheingold, A. L.; Martinez, T. J.; Craig, S. L. Inducing and Quantifying Forbidden Reactivity with Single-Molecule Polymer Mechanochemistry. Nat. Chem. 2015, 7, 323-327.

3. $\quad$ Song, Q.-W.; Yu, B.; Liu, A.-H.; He, Y.; Yang, Z.-Z.; Diao, Z.-F.; Song, Q.-C.; Li, X.-D.; He, L.-N. Peg400Enhanced Synthesis of Gem-Dichloroaziridines and Gem-Dichlorocyclopropanes Via in Situ Generated Dichlorocarbene. RSC Advances 2013, 3, 19009-19014.

4. $\quad$ Lee, M. K.; Rai, P.; Williams, J.; Twieg, R. J.; Moerner, W. E. Small-Molecule Labeling of Live Cell Surfaces for Three-Dimensional Super-Resolution Microscopy. J. Am. Chem. Soc. 2014, 136, 14003-14006.

5. $\quad$ Gossweiler, G. R.; Kouznetsova, T. B.; Craig, S. L. Force-Rate Characterization of Two Spiropyran-Based Molecular Force Probes. J. Am. Chem. Soc. 2015, 137, 6148-6151.

6. Bell, G. I. Models for the Specific Adhesion of Cells to Cells. Science 1978, 200, 618-627.

7. $\quad$ Barbee, M. H.; Kouznetsova, T.; Barrett, S. L.; Gossweiler, G. R.; Lin, Y.; Rastogi, S. K.; Brittain, W. J.; Craig, S. L. Substituent Effects and Mechanism in a Mechanochemical Reaction. J. Am. Chem. Soc. 2018, 140, 1274612750.

8. Lin, Y.; Barbee, M. H.; Chang, C. C.; Craig, S. L. Regiochemical Effects on Mechanophore Activation in Bulk Materials. J. Am. Chem. Soc. 2018, 140, 15969-15975. 